\title{
EliasZ NAUK. APOKALIPTYKA, PARACELSJAŃSKA MISTYKA PRZYRODY I NARODZINY NOWOCZESNOŚCI (CZĘŚĆ PIERWSZA)
}

\author{
MAREK WOSZCZEK
}

\begin{abstract}
Abstrakt: Mit Eliasza Artysty (albo „Eliasza nauk/sztuk”) jest jednym z interesujących komponentów bogatej szesnastowiecznej tradycji paracelsjańskiej z marginesów poreformacyjnej ortodoksji. Sygnalizuje zaskakujący kierunek rozwoju chrześcijańskiej tradycji apokaliptycznej, ponieważ ten „Helias artium chymicarum”, mesjański Experimentator jako ludzka, stylizowana na Chrystusa postać i odpowiednik biblijnego kowala Tubal-Kaina na końcu historii, jest oryginalną transformacja żydowskiego, apokaliptycznego Eliasza w kontekście wczesnej nowoczesności tuż przed wojną trzydziestoletnia. Jest to przykład z szerszego obszaru paracelsjańskiej teoalchemii (J. Telle), którą można interpretować jako typowo nowożytną hybrydę w latourowskim sensie. Co więcej, by zrozumieć szczególny poreformacyjny fenomen mistyki przyrody (Dorn, Weigel, Khunrath, Gutman, Arndt, Boehme $\mathrm{i}$ in.), pozostający w silnym napięciu z ortodoksyjnymi teologiami, należy wziąć pod uwagę, że był on wytworem tej nowej, szerokiej formacji intelektualnej, którą można nazwać przyrodniczą (albokosmologiczna) apokaliptyka.
\end{abstract}

Autor twierdzi, że „wertykalna” (nieeschatologiczna) apokaliptyka przyrodnicza jest wczesnonowożytną formą tradycji apokaliptycznej, która w nowych warunkach społecznokulturowych przeszła transformację w formułę „poznawania tajemnic przyrody” w złożo nym procesie renegocjacji relacji władzy i wytworzyła własny zasób motywacji poznawczych do aktywności eksperymentalnej, niezależnie od słabnących z czasem afektów 
millenarystycznych. Transformacja ta jest bardzo istotna dla zrozumienia religijnej wczesnej nowoczesności z jej immanentystycznymi, aktywistycznymi postawami i wyjścia poza jednowymiarowe dyskursy paradygmatu sekularyzacji, które zacierają albo ignorują wertykalna oś apokaliptyki i zafiksowują się na wymiarze horyzontalnym (millenarystycznym) w swoich konstrukcjach „irreligii postępu” (Löwith). Wczesną nowoczesność można lepiej zrozumieć jako rozproszony efekt związany z innowacyjnymi praktykami materialnymi, zwłaszcza medycznymi czy chemicznymi, oraz ich nowymi konceptualizacjami materii i wiedzy, gdzie filozofia, teologia, nauka o materii i społeczna rewolta wydaja się nierozdzielne. Mit Eliasza nauk, dokładnie odwrotnie do powierzchownej interpretacji sekularyzacyjnej, jest jednym z symptomów zachodzącego procesu „de-eschatologizacji” przez alternatywny kierunek apokaliptyki - przenoszenia zainteresowania na przyrodę i materię jako dostępne eksploracji obiekty religijne, co wytworzyło też nowe, typowe dla nowoczesności konflikty o władzę, ale i laboratorium jako przestrzeń odkrywania tego, co ukryte w przyrodzie.

Słowa kluczowe: wczesna nowoczesność, apokaliptyka przyrodnicza (kosmologiczna), mit Eliasza Artysty, mistyka przyrody, alchemia paracelsjańska, materia, panteizm, ontologia wyrażania 


\section{Wstęp: apokaliptyka przyrodnicza jako wczesnonowożytne medium epistemologicznych innowacji}

Eliasz zjawiał się w Europie wiele razy, ale być może najważniejsze jego pojawienie miało miejsce, gdy opadały twórcze, pogańskie energie renesansu, a wzbierała fala społecznoafektywnej rewolucji reformacji. Nowa formacja społecznych sił potrzebowała najwyraźniej własnego mesjasza, ale jego sylwetka nie przypominała już starożytnego Eliasza rabbich prawdopodobnie był to pierwszy mesjasz nowoczesności. Oznacza to, że również epoka nowożytna zaczęła się od swojej własnej apokalipsy, której ekscentryczność koresponduje z całkowicie suwerenną energią tej pierwszej. Nie musimy obawiać się, jak Blumenberg, o tę suwerenność i wymazywać religijnego afektu z historii jej autoasercji, o ile dopuścimy myśl, że ten nowy Eliasz był jednym z pierwszych barwnych tworów „Jeszcze-Nieświadomego" (E. Bloch) - wyłaniających się relacji i praktyk, które spontanicznie pomogły niszczyć wcześniejszą polityczną konfigurację i jej społeczne urządzenia. Nowe społeczne siły, wytwarzające nowe podmiotowości, wyprodukowały również nową, autonomiczną przyrodę, co wymusiło rewolucyjne przesunięcia w obrębie świadomości religijnej. Biblijny Eliasz zapowiedział się w tej fantazji jako mesjasz nowej religii przyrody i wróg dawnych reżimów prawdy, co stanowiło rzecz jasna aspekt większej batalii „nowożytników” ze „starożytnikami”. Szczegółowe historyczne zbadanie warunków, w których popularny deizm przyrodników czy Kantowska transcendentalna krytyka przyrodoznawstwa w końcu zaczęły wydawać się na dalszym etapie bardziej wiarygodne niż owa paracelsjańska religia przyrody i apokalipsa „Eliasza nauk”, zasługuje na oddzielną uwagę, co mogłoby też naświetlić beznadziejna sytuację, w jakiej znalazła się ortodoksyjna chrześcijańska teologia przyrody po nieodwracalnym załamaniu się scholastyki. Tak czy inaczej, gdy mowa o XVI i XVII wieku, kluczowym problemem jest zrozumienie zmiany konfiguracji poznawania, w tym redefinicji tego, co znaczy „doświadczać” (Shapin 2000, 63-107), a jednym z kluczowych nośników tej zmiany stała się apokaliptyczna ideologia deszyfrowania i ujawniania tajemnic „żywej księgi przyrody".

Niestety przez apokaliptykę wąsko rozumiało się dawniej i czasem nadal rozumie się kompleksy wyobrażeń, afektów i strategii interpretacyjnych koncentrujących się wokół dziejowego pesymizmu, walki dobra i zła, ich ostatecznej bitwy oraz intruzji końca świata jako katastrofy, który manifestować się ma antycypacyjnie za sprawą symbolicznych zdarzeń i „znaków”, signa temporum. A pokalipsa byłaby więc tu sprawą symbolu zaburzającego otwarta historię, który zakrzywia historyczny czas ku jego zamknięciu, kiedy traci on zwykła płynność realizowana przez stabilne konglomeraty powtarzanych społecznych praktyk, nawet jeśli są to praktyki transmisji i produkcji wiedzy (w tym sensie naturalnie rymowałaby się to więc także z szokiem rewolucji naukowej, ryzykiem przyszłości i masowymi przemianami społecznymi). 
Takie wąskie, millenarystyczne rozumienie apokaliptyki jest jednak błędne i nie odpowiada adekwatnie starożytnemu, judeochrześcijańskiemu fenomenowi apokalipsy, co wynika stąd, iż za wzorcowy tekst gatunku uznawana była od połowy XIX wieku, za Friedrichem Lücke i Eduardem Reussem, Apokalipsa św. Jana i związana z nią długa tradycja chrześcijańska (McGinn 1979). W istocie element millenarystyczny (chiliastyczny czy eschatologiczny) ni e jest w nim ani podstawowy, ani nawet definiujacy ${ }^{1}$, a starożytna apokaliptyka jest bezpośrednio sprzężona z narodzinami i kształtowaniem się żydowskochrześcijańskiej tradycji mistycznej. Apokalipsa nie dotyczy żadnego kolapsu kosmosu, globalnego kataklizmu, dziejowego pesymizmu, organizacji mesjańskiej wspólnoty ani kosmicznego rewanżu jako wyróżnionych tematów, lecz jest gatunkiem literatury objawieniowej, której osia jest ảંoká $\lambda v \psi \iota \varsigma$, ujawnienie w wizji, najczęściej przez nadludzką istotę (anioła) czy wysłannika podczas mistycznej podróży (uniesienia) wizjonera, u k r y t y ch

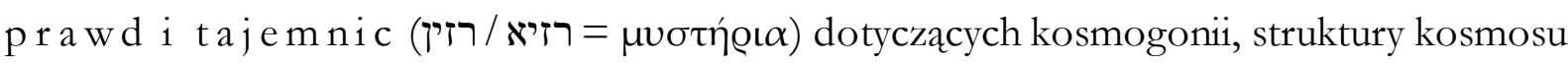
(kosmologii), astronomii, geografii i meteorologii², świata podziemnego, zaświatów, biegu historii i ludzkiego przeznaczenia wraz z seriami wskazówek, ostrzeżeń i napomnień.

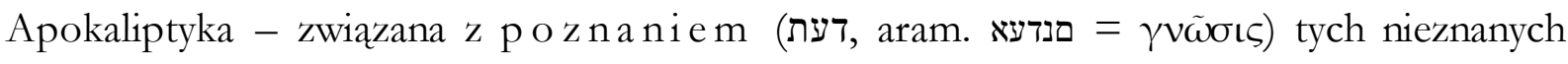
nawet rabbim i uczonym w Piśmie sekretów, ukrytych w podstawach świata i decydujących dla rozumienia przeszłości i nadchodzącej przyszłości, a nie z przepowiadaniem końca świata i miażdżącego zwycięstwa nad wrogami - posiada więc naturalne powinowactwo z k o s m o lo gia z jednej strony, i m is t y ka z drugiej, mimo iż chrześcijański millenaryzm z czasem obie je horyzontalnie neutralizuje $\mathrm{i}$ instrumentalizuje w ramach politycznie zdziczałej wyobraźni teologicznej. Zarówno wczesna żydowska i wschodniochrześcijańska ascetyczna mistyka, jak i późnoantyczna gnoza moga być rozumiane jako specyficzne metamorfozy wertykalnej apokaliptyki, również genetycznie ${ }^{3}$.

Od drugiej połowy XV wieku, po stuleciu dżumy, wznosząca fala apokaliptyki znowu stała się w Europie widoczna, ale o ile horyzontalny, niejednokrotnie agresywny millenaryzm jako apokaliptyka historyczno-eschatologiczna był kontynuacja jego średniowiecznych form zarówno w treści, jak i wyrazie ${ }^{4}$, o tyle zaskakujące jest wyraźne

1 Zob. zwł. kluczowe w historii badań prace: Scholem (1965), Brown (1968), Stone (1976), Rowland (1979, 1982), Collins (1979), Gruenwald (1973, 1980); w szerszym kontekście historycznym: Stone (1980).

2 Te tematy kosmologiczne są najczęściej ignorowane przez autorów biblijnych - tu zaś mają centralne znaczenie. Gruenwald (1973) słusznie podkreślał, że apokaliptyka z jej „ujawnianymi sekretami” leży na przeciwstawnym biegunie do pobożnościowej ideologii Księgi Hioba, akcentującej znikomość ludzkiego poznania.

3 Zob. np. szczegółowe przykłady wyłaniania się wczesnochrześcijańskiej ascetycznej mistyki jako uwewnętrznionej apokaliptyki w: Golitzin (2001, 141 i n.).

4 Tę kontynuację tłumaczyć można nie tylko względnym podobieństwem sytuacji społeczno-politycznego kryzysu i niestabilności struktur władzy (zob. np. McGinn 1979, 270 i n.), ale przede wszystkim ciaggłościa przekazu tekstów i inercja popularnych chrześcijańskich wyobrażeń millenarystycznych. 
ukazanie się w XVI wieku jej pierwotnej, „wertykalnej”, tj. przyrodniczokosmologicznej postaci. Było to możliwe dzięki rozrastającej się antykatolickiej i antyscholastycznej kontrkulturze oraz, co nie powinno dziwić, odkryciu wczesnośredniowiecznych żydowskich tekstów i tradycji mistyczno-kosmologicznych (protonaukowych), które w dość nieoczekiwany sposób pomogły nawet po reformacji torować drogę nowej philosophia naturalis. Pytanie, w jakim stopniu spekulatywnokosmologiczny typ apokaliptyki wraz z renesansową mentalnością hermetyczną dostarczały rodzącej się nauce motywacji poznawczej i impetu, jest osobną, od dawna gorąco dyskutowaną kwestia (od czasu studiów Yates, McGuire’a, Rattansiego, Webstera czy Debusa z lat 60. i 70. XX wieku ${ }^{5}$ oraz odkrycia dla historii nauki siedemnastowiecznej hermetycznoalchemicznej subkultury naukowej, poprzedzonych słynną, ukończoną w 1958 r. History of Magic and Experimental Science Lynna Thorndike'a), ale skoncentruję się tu na rozwoju apokaliptycznej religii przyrody na obrzeżach świata protestanckiego jako fenomenu epoki przejścia i zarazem symptomu postscholastycznego kryzysu chrześcijańskiej teologii i filozofii. Właśnie w nawiasie tego kryzysu przejścia rodziła się nowoczesność, a przyroda oraz materia były w tym procesie kluczowymi aktorkami, nawet - a może przede wszystkim - na scenie religii ${ }^{6}$. Wczesną nowoczesność można próbować rozumieć także poprzez tę nowa, suwerenną apokalipsę.

W pierwszej części rozważań zajmę się mitem Eliasza Artysty jako oryginalnym wytworem porenesansowej mentalności i sposobem, w jaki zaburzył on tradycyjny chrześcijański millenaryzm. Położę nacisk na kilka szczególnych aspektów szerokiej formacji paracelsjańskiej, która posługiwała się tym mitem w walce ze scholastyką i religijną ortodoksją: nowe, dynamiczne rozumienie materii i panteistyczny trend, który ukształtował w drugiej połowie XVI wieku „chrześcijaństwo chymiczne”, czyli chrześcijańską religię przyrody. Należy ją rozumieć jako wczesnonowoczesną postać apokaliptyki przyrodniczokosmologicznej, która służyła jako pole redefinicji praktyk protonaukowych i politycznej walki o nowe układy wiedzy-władzy w poreformacyjnej Europie. Przedstawię mit Eliasza nauk jako spontaniczny produkt religijnej ontologii nowych praktyk wiedzotwórczych w sytuacji społecznej niestabilności. Ontologia ta pracowała nawet po wygasaniu millenarystycznego podniecenia po wojnie trzydziestoletniej, gdyż była od niego niezależna: „apokaliptyka zawiera w sobie ziarna zniszczenia historycznej eschatologii” (Rowland 1982, 445).

\footnotetext{
5 Zob. zwł. Yates (1964), McGuire i Rattansi (1966), Rattansi (1972), Webster (2002 [1975]; 1992 [1982]) czy Debus (1977); zob. także Copenhaver (1990) i von Greyerz (1999).

${ }^{6}$ Przyjęta przeze mnie perspektywa jako pomocna w rozumieniu wczesnej nowoczesności jest podobna do tej, którą ostatnio zaprezentowali Anne-Charlott Trepp (1999; 2009) czy Kocku von Stuckrad (2010).
} 
W części drugiej skoncentruję się na heterodoksyjnej mistyce przyrody, którą apokaliptyka ta wytworzyła jako swoją uwewnętrznioną formę i na kryzysie ideologiczno politycznym, który zaczęły one razem wywoływać na przełomie XVI i XVII wieku. Będę argumentowal, że jako nośniki religijnych afektów obie miały one - ze swoimi wewnętrznymi napięciami i wytwarzanymi hybrydami - duże znaczenie w wyłanianiu się wczesnej nowoczesności z jej zmienionym układem społecznych sił i polaryzacją dyskursów. By to opisywać i wyjaśniać, nie jest potrzebna ani globalna dialektyka sekularyzacji, ani tym bardziej żadna ponura, konserwatywna historiozofia - same już dyskusje o „prawomocności nowoczesności” sa konsekwencją ignorowania socjologii wiedzy, a także historii i ontyki innowacyjnych praktyk społecznych (na samym druku począwszy), nagminnie naruszających pola ustabilizowanych wcześniej struktur wiedzy-władzy, od religijnej po administracyjna. Praktyki te spowodowały między innymi, że polityka sekretu i zdobywania, dystrybucji oraz kontroli wiedzy wysunęła się na pierwszy plan (zob. np. Jütte 2015; Eamon 1984, 1994). To prawda, że nowoczesność funkcjonuje jakby była epoką sekularna i jakby polegała na sekularnym odwróceniu religijnych zainteresowań, ale dla historyka jest to sugestywna iluzja wykrojenia rozległego „Państwa Środka” (Latour 2011, 72), które potajemnie rządziło afektami nowoczesnych. Jedno jest prawdą: to „Państwo Środka” zaczęło się międ zy innymi rozrastać dzięki napędzającym się seriom epistemologicznych innowacji („reformacjom”) sprzęgniętym z konfliktami religijnymi.

\section{Paracelsjański mit Eliasza Artysty: mesjasz nauk i sekrety materii}

Mesjańska postać „Eliasza Artysty”, [H]Elias artista, czy „Eliasza sztuk/nauk”, element ezoteryczno-apokaliptycznych wyobrażeń XVI i XVII wieku, pojawia się po raz pierwszy u Paracelsusa ${ }^{8}$ i od razu posiada intrygujący charakter, różniący ją od pierwotnej postaci Eliasza-proroka z Samarii występującego w bardzo popularnej tradycji żydowskiej, zarówno rabinicznej, jak i ezoteryczno-kabalistycznej oraz w żydowskim folklorze (zob. np. Lindbeck 2010). W tej ostatniej Eliasz, uniesiony do nieba na ognistym rydwanie Bożym zgodnie z opowieścią z 2 Księgi Królewskiej 2,11, jest wielkim wtajemniczonym, który u kresu czasów ujawni ludziom prawdziwe znaczenie wszystkich ustępów Tory (stąd fraza „do czasu nadejścia Eliasza” z egzegetycznych pism rabinicznych, odnosząca się do nierozwiązanych

\footnotetext{
${ }^{7}$ Najlepsze omówienia motywu Eliasza Artysty dają: Pagel (1981), Breger (1984), Gilly (1997) i najnowsze, wyczerpujące studium z pełną bibliografia: Faivre (2002 i 2003). Zob. też uwagi w: Peuckert (1973, 34 i nast.), Newman (1994, 3-13) i Newman (1998, 127 i n.), Goldish (2004, 21 i n.) oraz Wollgast (1993a, 118 i n.).

8 Syntetyczny przegląd nowszych badań nad Paracelsusem np. w: Prinke (2014, 299-321). Klasyczne obszerne studia to Goldammer (1953; 1986) i Pagel (1982), zaś nowsze omówienie daje np. Weeks (1997). Krótkie, krytyczne wprowadzenie do doktryny paracelsjańskiej np. w: Moran (2006, 67-98). Omówienie historii ruchu paracelsjańskiego można na przykład znaleźć w: Trevor-Roper (1985).
} 
jeszcze problemów interpretacyjnych). W popularnej literaturze religijnej z rodzaju „objawień Eliasza", גלוי אליהו, służył jako mistyczne źródło wiedzy o sprawach boskich, nauczyciel rabbich, moralny wzór i objawiciel ukrytej wiedzy. W tradycji antycznej miał on też być arcykapłanem czasów ostatecznych i zwiastunem epoki zbawienia - jego i Mojżesza symbolizują dwa drzewka oliwne przed Bogiem-,,Panem ziemi” z wizji proroka Zachariasza (Za 4,3.11-14) i Apokalipsy św. Jana (11,3-4)9. W Księdze Syracha (Syr 48,10) mówi się, że Eliasz został przez Boga „zachowany na odpowiednie czasy”, przez co rozumiano rzecz jasna czasy mesjańskie, „odnowienia pokolenia Jakuba”, a więc jego pojawienie się zapowiada nadejście mesjasza, które będzie obwieszczał $z$ góry Karmel. Istniały też tradycje identyfikujące go z esseńskim, wspominanym w qumrańskim tzw. Dokumencie Damasceńskim „Nauczycielem Prawdy” i „Nauczycielem Zjednoczenia” ${ }^{10}$. Żydowscy mistycy średniowieczni (począwszy na langwedockich, takich jak Abraham ben Dawid z Posquières, Jakub ben Saul ha-Nazir czy Izaak Ślepy), ale też Izaak Luria i jego uczniowie twierdzili, że otrzymywali wtajemniczenia w boskie sekrety za jego pośrednictwem, co nie było późną ekstrawagancją, lecz stanowiło spójną tradycję o starożytnych korzeniach - według legendy miał on osobiście, wraz z aniołami, przekazywać ezoteryczne tajemnice rabbiemu Szimonowi ben Jochajowi zapisane w Zoharze (sam Eliasz ma tam de facto status bez mała anielski, jest człowiekiem wyniesionym ponad status czysto ludzki). Interesujące jednak, że w tej tradycji żydowskiej w odróżnieniu od postaci samego mesjasza, będącego postacią królewską i prorocką zarazem, Eliasz reprezentuje duchową siłę w sensie intelektualnego i zarazem mistycznego wglądu (wtajemniczenia i wiedzy), co zbliża go właśnie do chrześcijańskiego Eliasza paracelsjańskiego. Nie ulega wątpliwości, że od przełomu XIII i XIV wieku Eliasz miał na nowo kluczowe znaczenie w żydowskiej tradycji kabalistycznej - de facto jego postać, co podkreślał Gershom Scholem (1987, 35 i n.), odegrała istotną rolę w budowaniu tej tradycji w Europie.

Apokaliptyczna rola Eliasza pojawiła się nieoczekiwanie w zachodnim świecie chrześcijańskim u Joachima di Fiore i Guillaume’a Postela, wreszcie zaś w pierwszej fali reformacji, gdy sam Luter nazywany bywał - zwłaszcza przez niektórych późniejszych gnezjoluteran i nie bez wkładu Melanchtona - „trzecim Eliaszem” (i ostatnim, po Janie

${ }^{9}$ Zob. np. Koester $(2014,439$ i n.).

10 Dokument, odnaleziony w 1896 r. w Kairze, opublikowany został w 1910 r. w Cambridge. Kolejne fragmenty zostały zidentyfikowane wśród rękopisów znalezionych z czwartej, piątej i szóstej grocie w Qumran. $\mathrm{Na}$ temat związku między Eliaszem i esseńskim Nauczycielem (zob. np. Burrows 1952). Nauczyciel Sprawiedliwości, jak Eliasz, nie jest po prostu mędrcem objaśniającym zawiłości Tory, lecz „ma wgląd we wszystkie sekrety” (1QpHab 7.4-5; Muchowski 1996, 5) - są to zapewne owe „sekrety zamysłu” Boga, „cudowne sekrety” i „wszelka mądrość”, o których mówi też 1QH 5.6-8 (Muchowski 1996, 61). 
Chrzcicielu) $)^{11}$, a Müntzer i anabaptyści powoływali się na „ducha Eliasza” lub wprost głosili jego nadejście (Breger 1984, 52) ${ }^{12}$. Dla luterańskich czytelników Nowego Testamentu ta ezoteryczna symbolika miała jasne korzenie: w Ewangelii Mateusza 17,11 Jezus mówi, iż

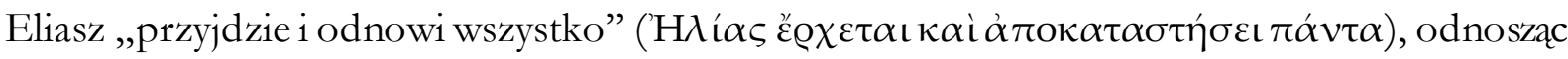
te słowa do Jana Chrzciciela. Podobnie wcześniej (11,7-19) mówi o nim wprost: „on jest Eliaszem, który miał przyjść (ó $\mu \varepsilon ́ \lambda \lambda \omega \nu$ é@ $\chi \varepsilon \sigma \theta \alpha \iota)$ " i przedstawia go nie tylko jako posłańcaherolda, ale „więcej niż proroka” $(11,9)$. W tradycji chrześcijańskiej postać ta uległa więc modyfikacji wskutek otwartego utożsamienia historycznego Jezusa z oczekiwanym mesjaszem: ten, kto go poprzedza i chrzci w Jordanie, czyli Jan Chrzciciel, sam musi być odrodzonym Eliaszem. Półtora tysiąca lat później czasy reformacji miały więc być po prostu czasami „nowego Eliasza”, jego obecności zapowiadającej Paruzję - w pełnej zgodności z dawna wizja Joachima di Fiore. Eliasz Joachima z jego Tractatus super quattuor Evangelia miał pojednać wszystkich chrześcijan, zebrać ich przy jednym ołtarzu i rozpocząć epokę całkowicie spirytualistyczna, powszechnego wylania Ducha Świętego, ukazanego działaniem „nowego zakonu” (zastępującego hierarchię Kościoła) i odkryciem przed ludźmi wszystkich tajemnic Pisma Świętego. Luterańscy apokaliptycy przywiązywali ogromną wagę do wersetu kończącego Księgę Malachiasza (3,23), gdzie Bóg oznajmia: „Oto poślę wam proroka Eliasza, zanim przyjdzie wielki i straszny dzień Pana". Za sprawą Melanchtona i Chronicon Carionis ${ }^{13}$ „proroctwo Eliasza”, vaticinium Eliae, na temat trzech wielkich epok i sześciu tysięcy lat historii przedostało się do głównego nurtu duchowości luterańskiej: przynajmniej niektórzy autorzy zdawali sobie jednak sprawę, że jest to proroctwo całkowicie apokryficzne i w pewnej mierze ezoteryczne, przypisując je żydowskim źródłom kabalistycznym czy ogólnikowo przytaczanej „wiedzy Żydów” (Barnes 1988, 78). Istotnie, pochodzi ono z Talmudu Babilońskiego ('Aboda Zara 9a) i było podstawą licznych rabinicznych spekulacji, zanim trafiło na grunt protestanckiej apokaliptyki.

Ale Eliasz Artysta, „wielkie światło” z proroctwa Paracelsusa, to nowe i oryginalne wcielenie tej tradycji, bezpośrednio torujące drogę alchemicznemu mesjanizmowi paracelsjańskiej subkultury drugiego i trzeciego pokolenia po Lutrze. Sam Paracelsus również

11 Zob. np. Preuss (1933, 49 i n.). Zarówno Melanchton, jak i Zwingli wprost nazywali Lutra Eliaszem w walce z rzymskokatolickimi „kapłanami Baala” - ten pierwszy jednak w zdecydowanie millenarystycznym kontekście, zob. np. Petersen (2013, 82 i n.).

$12 \mathrm{Na}$ przykład Melchior Hoffmann, jeden z głównych przywódców anabaptystów, głosił, iż reprezentuje Eliasza - podobnie zresztą sądzili o nim niektórzy spirytualistyczni reformatorzy z kręgu tzw. proroków strasburskich.

13 Chronicon (1531-1532) skompilowany został po niemiecku przez astronoma i astrologa Johanna Cariona (1499-1537), ucznia Melanchtona, który sam przełożył na łacinę, gruntownie przerobił i rozszerzył pracę Cariona, opatrując ją przedmową - dwa pierwsze tomy, kończące się na czasach Karola Wielkiego, ukazały się w Wittenberdze w latach 1558-60 (Melanchton 1558; przedruk w: Melanchton 1844, 709-1094). Carion służył jako nadworny astrolog na dworze elektora brandenburskiego. Zob. zwł. Bauer (1999, 203-246); także Barnes (1988, 106 i n.) i Schmidt-Biggemann (2004, 403 i n.). 
był chrześcijańskim, gorąco utopistycznym apokaliptykiem, związanym na krótko z górniczochłopska rewolta anabaptystów w Salzburgu (Pagel 1982, 17) i oczekującym nastania w opozycji do papiestwa i cesarstwa - nowej rzeczywistości na ziemi, opartego na równości i sprawiedliwości „złotego świata” i „Nowego Królestwa” (czy „Nowego Hebronu”) ${ }^{14}$, którego heroldem miał być Eliasz. Jego wizja ma jednak wyjątkowy charakter ze względu na program odnowy ludzkiego świata oparty na nowej nauce, nowej medycynie i pogłębieniu poznania natury (zob. np. Breger 1984, 55 i n.). Wrogość i pogarda Paracelsusa wobec scholastyki, „papistowskiej teologii” i starej kosmologii jest tak bezprecedensowa, że czasem trudno historykowi idei oprzeć się pokusie odnajdywania w jego inwektywach jednego z barwnych, ale niezawodnych symptomów rodzącej się, autoasertywnej nowoczesności: „srać na waszego Pliniusza i Arystotelesa, srać na waszego Alberta, Tomasza, Szkota i na pozostałych"15. Jego były asystent, Oporinus, denuncjował, że Paracelsus miał chęć wysłać tak Lutra, jak papieża z powrotem do szkoły albo raczej do laboratorium, by nie opowiadali jak nieuki - bzdur ${ }^{16}$. W Paragranum ośmielił się wystosować słynne wezwanie do praktyków medycyny i chymii, odpowiadając na skierowaną na niego, jak mówi, „faryzejską” agresję: „Idźcie za mna, Awicenno, Galenie, Razesie, Montagnano, Mesuesie i inni. Idźcie za mna, a nie ja za wami! Wy z Paryża, wy z Montpellier, wy ze Szwabii, wy z Miśni, Kolonii i Wiednia, z wybrzeży Dunaju i Renu, (...) wy Grecy, Arabowie, Izraelici, idźcie za mna, a nie ja za wami! Nikt z was się nie uchowa w najdalszym choćby zakątku, w którym nawet psy nie szczaja. To ja będę władcą i ja będę rządził" (Paracelsus 1924b, 56) ${ }^{17}$. Kontemplatywne nastawienie scholastyki, substancjalne formy - owe „mizerne byty” (Kartezjusz) ${ }^{18}$, actus purus oraz causae finales scentrowanego wszechświata zostają wyrzucone na śmietnik (rozpoczyna się Telosschwund Blumenberga, który w pełni widać już u Bruna i Kartezjusza - Blumenberg 1974, 159 i n.), otwierając jednocześnie nowe możliwości badania wszechświata i materii oparte na nowej mentalności ostentacyjnie ignorującej dawne autorytety (zob. np. Shapin 2000, 63-76).

\footnotetext{
${ }^{14}$ Zob. np. Goldammer (1986, 157), Goldammer (1948), Wollgast (1993a, 118 i n.).

15 Paracelsus (1924a, 138): ,wie dünket euch, so ir werden in mein philosophei müssen und auf eueren Plinium, Aristotelem scheissen, auf eueren Albertum, Thomam, Scotum etc. seichen..." (cyt. też w: Prinke 2014, 307). Andrew Weeks $(1997,46)$ zastanawia się, czy to możliwe, że nobliwi niemieccy badacze Paracelsusa poprzednich pokoleń mogli odczuwać dyskretna przyjemność z tych inwektyw szesnastowiecznego rewolucjonisty. Jedno jest pewne: ich adresaci zostali dobrze dobrani, choć do listy należałoby dodać jeszcze zapewne Galena i Awicennę, którego medyczny Kanon Paracelsus publicznie spalił jako wykładowca medycyny na Uniwersytecie w Bazylei w czerwcu 1527 r., tak jak Luter spalił w 1520 r. bullę papieską i księgę prawa kanonicznego.

16 Theodor Zwinger, Theatrum humanae vitae (1571), cyt. za: Gilly (1994, 426): „Wann er (Paracelsus - przyp. M.W.) anfieng zu schreiben, wolte er sy (Lutra i Zwinglego - przyp. M.W.) und auch den Bapst erst recht in die schiil füren".

${ }^{17}$ To charakterystyczne zawołanie Paracelsusa, ,mir nach und nit ich euch nach”, wraz z końcowym proroctwem zwycięstwa nad „faryzeuszami nauk” i religijnymi fanatykami „od papieża i Lutra”, można chyba potraktować jako bojowy okrzyk wczesnej nowoczesności. Późniejsi paracelsyści traktowali Paracelsusa właśnie jako „króla” nowej „monarchii”' (= paradygmatu) medycyny i religii.

18 „... I pojęliśmy, że owe mižerne byty do niczego innego nie są użyteczne, jak tylko do zaślepiania umysłów studentom i do wtłaczania im (...) jakiejś zarozumiałej ignorancji”' (Descartes 1996, 37).
} 
Przyroda owego pewnego siebie, ewangelicznego medyka skrywa, owszem, swe sekrety założone przez Boga w jej królestwach (mineralnym, roślinnym i zwierzęcym), ale zadaniem przyszłości jest nieustępliwe badanie tych sfer dla dobra człowieka, zgodnie ze współrzędnymi wyznaczonymi jeszcze przez renesansowo-humanistyczną wizję (sam Paracelsus związany był z kręgami humanistów z Bazylei, gdzie od 1527 r. pełnił funkcje profesora medycyny i lekarza miejskiego, zob. np. Hemleben 1973 oraz Goldammer 1964). Eksploracja ukrytych warstw przyrody i wykorzystanie tej wiedzy staja się tu najszlachetniejszymi zadaniami człowieka (Wollgast 1993b, 656).

Eliasz Artysta to mesjasz chymii, kosmologii/astronomii i filozofii, Experimentator, mag-fizyk-chemik wtajemniczony w sekrety materii i historii kosmosu - podobnie jak „Chrystian Rosenkreutz” ze słynnych, późniejszych tak zwanych manifestów różokrzyżowych, Famy Fraternitatis i Confessio ${ }^{19}$ - i model chrześcijańskiego mędrca przyszłej epoki: w tradycji paracelsjańskiej jest on de facto ideałem chrześcijańskiego chemika i lekarzauzdrowiciela w jednej osobie. Określenie „Artysta” („Artista”, dodane już przez anonimowego pisarza postparacelsjańskiego ok. 1570 r. w Libellus de tinctura physicorum ${ }^{20}$ ) odnosi się oczywiście i do nauk (szerzej niż artes quadriviales, w tym także filozofia) ${ }^{21}$, i par excellance Sztuki-Ars, tj. badania materii (alchemii-chymii i medycyny-farmacji zarazem), którego rozwój ma umożliwić przemianę świata i człowieka, „gdyż nauki mają swojego Eliasza tak samo, jak maja go inne dziedziny (religia - przyp. M.W.)"22. W swym stosunkowo wczesnym piśmie De mineralibus Liber (O minerałach) z ok. 1529 r. Paracelsus przewiduje rychłe nadejście Eliasza: „Jest ponadto prawda, że nie ma nic ukrytego, co nie miałoby zostać ujawnione, i dlatego nadejdzie po mnie wielki człowiek, który jeszcze nie żyje, i który wyjawi

\footnotetext{
19 Allgemeine und General Reformation der gantzen weiten Welt. Beneben der Fama Fraternitatis, Dess Löblichen Ordens des Rosenkreutzers, an alle Gelehrte und Häupter Europae geschrieben, Kassel 1614; Fama Fraternitatis R.C. (...), beneben deroselben lateinischen Confession oder Bekandnuss der löblichen Bruderschafft dess hochgeebrten Rosen Creutzes an die Gelebrten Europae geschrieben, Kassel 1615. W 1615 i 1616 r. ukazały się też kolejne łączne wydania obu tekstów, w tym gdańskie Hünefelda: Fama Fraternitatis Oder Entdeckung der Brüderschafft des löblichen Ordens dess Rosenkereutzes. Beneben der Confession Oder Bekantnuss derselben Fraternitet, an alle Gelebrte und Häupter in Europa geschrieben, Danzig 1615 (dalej: FFG), które jest przedrukiem wydania frankfurckiego z 1615 r. Pierwsze wydanie krytyczne Famy z uwzględnieniem manuskryptu salzburskiego: van der Kooij i Gilly (1998, dalej: FFU). Obecnie jest już dostępna pełna edycja krytyczna manifestów na podstawie wszystkich znanych rękopisów (odpisów) i pierwszych druków: Andreae (2010, dalej: R). Przekład polski Famy i Confessio autorstwa Jerzego Prokopiuka: Andreae (2006, dalej: FFP). Zob. też: Gilly (1995, 69-79, edycja gdańska: 76) i dobre wprowadzenie w jęz. pol.: Prinke $(2014,530-552)$.

20 Paracelsus (1933a, 396); zob. też: Faivre (2002, 122).

21 Ze względu na charakter eksperymentalny, włączenie nowych dziedzin wcześniej wykluczonych oraz gwałtowną wrogość paracelsystów do dawnych i uniwersyteckich artes, mówienie o „Eliaszu sztuk” staje się problematyczne - właściwe jest już mówienie o „naukach”, pomimo współczesnej niechęci do kojarzenia ich z alchemią i magią. Moja optyka jest tu zbieżna ze stanowiskiem B.T. Morana (2006) czy J. Henry’ego (2008).

22 Paracelsus (1930a, Cap. VIII: Vom Vitriol, 163): „dan die künst haben gleich so wol Heliam, als sonst zuverston ist'”.
} 
te rzeczy"23. W istocie, zgodnie z pseudoparacelsjańskim proroctwem z De tinctura physicorum wierzono, iż miał nadejść pięćdziesiąt osiem lat po jego śmierci, czyli w samym końcu XVI wieku. Niektórzy hermetyczni paracelsyści precyzyjnie wyliczali moment tego nadejścia i początek nowej ery na rok 1603, spodziewając się wówczas nadejścia wielkiego reformatoraproroka (Barnes 1988, 218). Wśród nich był w Tybindze utrzymujący szerokie kontakty religijny, apokaliptyczny paracelsysta, prawnik i praktykujący medyk Tobias Hess z Norymbergi (1558-1614), „Hercules Christanus” - centralna, charyzmatyczna postać szerszego, nieformalnego środowiska heterodoksyjnych pietystów z otoczenia tamtejszej Akademii Teologicznejej, z którego wyszły zarówno Fama jak i Confessio (ich anonimowym autorem był z pewnościa Johann Valentin Andreae, oddany przyjaciel Hessa, ale zostały wydrukowane bez jego zgody, a może nawet wbrew woli).

Sam zresztą Paracelsus, który używa nawet - jak później jego uczniowie rabinicznej formuły „bis auf die zeit der künst Helias, so er komen wird” (,aż do czasu nadejścia Eliasza sztuk" ${ }^{25}$, mógł oczywiście kierować się astrologicznymi obliczeniami przewidujacymi na lata 1603-1604 słynną coniunctio maxima, potrójną koniunkcję planet Jowisza, Saturna i Marsa, co elektryzowało całą Europę. Tłumaczy to może, dlaczego apokaliptycznoalchemiczny obraz Eliasza, obecny u takich alchemików jak Michael Toxites, Gerhard Dorn, Alexander von Suchten, Adam Haslmayr, Michał Sędziwój, Oswald Croll, Johannes Montanus ze Strzegomia, Jan Baptysta van Helmont czy Irenaeus Agnostus, zyskał w2. połowie XVI w. zaskakująco rosnące znaczenie, tak że w czasie powstawania różokrzyżowych manifestów stanowił ważny element rozwijającej się bujnie ezoteryki paracelsjańskiej ${ }^{26}$. Nie dla wszystkich było to jednak jasne. W 1623 r. krytyk „herezji RóżoKrzyża”, erudyta Gabriel Naudé (1623, 42-52) zauważył w swojej Instruction à la France..., iż Eliasz Artysta przypomina „Eliasza Pandochaeusa” Guillaume’a Postela, katolickiego utopisty

\footnotetext{
23 Traktat umieszczony w Opera Omnia Paracelsusa (Genewa 1658, fol. II) oraz jako Das Buch De Mineralibus w: Paracelsus $(1930 \mathrm{~b}, 46):$ „... das ist noch auch war, nichts ist verborgen, das nit offenbar werd, darumb so wird nach mir kommen, des (magnal) noch nicht lebt und es ofnen".

24 Byli wśród nich młody Johann Valentin Andreae (1586-1654), jeden z najwybitniejszych teologów wirtemberskich XVII wieku, a także takie postaci jak: wybitny jurysta swoich czasów, mianowany w $1610 \mathrm{r}$. profesor prawa rzymskiego w Tybindze i wielokrotny kanclerz uniwersytetu Christoph Besold (1577-1638); jego brat, również profesor prawa, Johann Georg Besold (1580-1625); prawnik Thomas Lansius (1577-1657), profesor tybingeńskiego Collegium Illustre; Johann Jakob Hainlin (lub Heinlein, 1588-1660), późniejszy profesor matematyki, którego instruktorem był Kepler; czy studiujący w Tybindze od marca 1607 r. późniejszy orientalista, matematyk, astronom i geograf, konstruktor (na zlecenie swojego przyjaciela Keplera) pierwszego mechanicznego kalkulatora („liczącego zegara”) i profesor języka hebrajskiego Wilhelm Schickard (1592-1635). Zob. np.: Brecht (1977, 270-343; 1993, 113-203; 1967), Wollgast (1993b, 263-282), Dickson (1998, 22-40), Gilly (1986).

25 Paracelsus (1930a, Cap. VIII: Vom Vitriol, 163). Na przykład oddany uczeń Paracelsa Gerhard Dorn $(1659,537)$ używa w swojej De transmutatione metallorum for muly: „, usque in adventum Heliae Artistae quo tempore nibil tam occultum quod non revelabitur".

26 Ten wątek tradycji paracelsjańskiej ukazał na przykład Walter Pagel (1981); zob. więcej w: Faivre (2002, 123-130).
} 
„wielkiej instauracji” (zob. Faivre 2002, 119 i n.). Współcześnie sugerowano, iż pierwotnie mogło chodzić nie o Eliasza biblijnego, lecz przede wszystkim Eliasza z Kortony, towarzysza Franciszka z Asyżu i dwukrotnego generała zakonu franciszkańskiego, który zgodnie z tradycja miał być alchemikiem i któremu przypisywano nawet autorstwo niektórych traktatów (np. Liber Saturnini czy Liber Eliae de alchimia). Jest to jednak nieporozumienie: jak słusznie argumentował Carlos Gilly ${ }^{27}$, od samego początku wątek biblijno-joachimicki odgrywał centralną rolę u Paracelsusa i jego szesnastowiecznych czytelników. Co więcej, słusznie podkreślił on fakt, iż duża część pojedynczych prac Paracelsusa, które drukowano po 1605 r. aż po lata 30., były właściwie tekstami zawierającymi proroctwa, co odzwierciedla postrzeganie samego Paracelsusa jako proroka, który zapowiedział zbliżające się wydarzenia o wielkim duchowym i politycznym znaczeniu (Gilly 1994, 449). Dla teologicznie zorientowanych, antykatolickich czytelników ten aspekt był szczególnie interesujący i pozwalał nawet na ukrycie bardziej heterodoksyjnych przekonań. Christoph Besold z pietystyczno-ezoterycznego kręgu Tybingi zapisał na przykład w 1916 r. w swoich Aksjomatach...:

\begin{abstract}
Wspaniałość Najświętszego Pisma jest tak wielka, że proroctwa są Odbiciami (Typi) nadchodzących kolejno czasów; i nie wystarczy, że każda jedna rzecz przepowiedziana, wypełnia się raz jeden. Tak też Jan, objęty duchem i prawością Eliasza, poprzedzał Chrystusa, a jednak wzmianka o powrocie Eliasza jest w 2. rozdziale Apokalipsy (Besold 1616, 228 i n.).
\end{abstract}

Besold, jak inni luterańscy interpretatorzy Apokalipsy, przywołuje tutaj proroctwo z Ap 11,3, iż Eliasz wraz z Mojżeszem ponownie nadejdą w czasie szóstej trąby, będą prorokować („składać świadectwo”) przez 1260 dni obdarzeni nadnaturalnymi mocami, aż zostaną pokonani i zabici przez Bestię z otchłani, a ich trupy leżeć będą na ulicy upadłego miasta. Jednakże w kręgach ezoterycznych, postaci Eliasza millenarystycznego i Jana Chrzciciela stapiały się już z heterodoksyjnym, paracelsjańskim Eliaszem chymii. Na tym późnym etapie, kilkadziesiąt lat po śmierci Paracelsusa pojedyncze wzmianki z jego pism rozrastają się już w całą mesjanistyczną religie „,nowej nauki”, której obsesją jest sama przyroda, produkująca kwasy i metale tak samo jak zwierzęta i ludzi, tak, że medycyna staje się nierozdzielna od chemii, a filozofia od astronomii i geologii.

Jako przykład może tu posłużyć kalwiński teolog, alchemik i hermetysta związany z dworem Maurycego „Uczonego”, landgrafa Hesji-Kassel - Raphael Eglin (1559-1622) i jego opublikowana pod pseudonimem „Nicolaus Niger Hapelius, Anagrammatizomenos”

${ }^{27}$ Gilly $(1997,63$ i n.) - wbrew wcześniejszej opinii Pagela, który uważał, że dopiero wtórnie utożsamiono Eliasza Artystę z Eliaszem biblijnym, jak czynił na przykład w 2 poł. XVII w. Knorr von Rosenroth. Tego samego zdania co Gilly jest na przykład William R. Newman (1994, 3). 
praca Cheiragogica Heliana de Auro Philosophico (1612), która - jak wskazuje sam tytuł - jest w zasadzie alchemicznym komentarzem osnutym wokół proroctwa o nadejściu Eliasza (Åkerman 1998, 118; zob. Pagel 1981, 11 i n.). Zawiera ona między innymi pismo Disquisitio de Helia Artium (Rozprawa o Eliaszu Nauk), którego pierwsze wydanie ukazało się, pod prawdziwym nazwiskiem autora, w Lipsku w 1606 r. oraz w Marburgu tego samego roku (sygnowane „Heliophilus à Pereis”) ${ }^{28}$. Eglin, diakon katedry w Zurychu, musiał uciekać stamtąd w związku z oskarżeniami o herezję i otrzymał od landgrafa posadę na wydziale teologicznym Uniwersytetu w Marburgu jako profesor Nowego Testamentu: był praktykującym alchemikiem i należał do pierwszych entuzjastów idei Różo-Krzyża, którą rozumiał, jak wielu innych, ściśle alchemicznie. To on też napisał zapewne tekst Assertio Fraternitatis R.C. (Frankfurt 1614), którego autor przedstawia się jako członek Bractwa, dysponującego dzięki znajomości natury możliwościami chemiczno-magicznego przygotowywania lekarstw (Moran 1994, 113) ${ }^{29}$. Mesjańska postać Eliasza Artysty pojawia się również w tym samym czasie u zaprzyjaźnionego z Eglinem alchemika Benedictusa Figulusa w jego Thesaurinella Olympica aurea tripartita (Ztoty olimpijski skarbczyle, Frankfurt 1608), który nawet sugeruje, że może on już żyć i działać na ziemi. Podobnie też u Juliusa Sperbera (który w duchu Zoharu nazywa go po prostu „Angelus Dę”), a także zbuntowanego jezuity i żarliwego paracelsysty Adama Haslmayra w jego tekście dołączonym do pierwszego druku Famy z 1614 r. (Breger 1984, 60; Faivre 2002, 131). Figulus napisał w 1607 r. opublikowany w Thesaurinella... list dedykacyjny do Rudolfa II, w którym wyjaśnił cesarzowi swoje paracelsjańsko-mesjańskie zapatrywania i oczekiwanie na Eliasza Artystę, „prawdziwego Mysteriarchę oraz Objaśniacza boskich Magnaliów i tajemnic Boga”. Według Figulusa Eliasz poprzedzi Paruzję (będąc „Vorbott und Praecursor CHRISTI IESU”) i rozpocznie odnowę wszystkich nauk przez apokalupsis tajemnic kosmosu, jak zapowiedział „Theophrastus” ${ }^{30}$. Croll $(1623,5)$ nazywa tego chymicznego „Elias der Artist’, pisząc o odnowionej przez ogień „trzeciej epoce” Ducha świętego, „Reparator omnium” (Odnowicielem/Odkupicielem wszystkiego).

Idee takie jak te prezentowane przez Eglina, Figulusa, Crolla czy Haslmayra, krótko potem krążące już wśród uczniów i zwolenników Boehmego, w szczególności w kręgu Abrahama von Franckenberga, nie były ani prostymi adaptacjami motywów średniowiecznej alchemii, ani rozszerzonym religijno-kościelnym millenaryzmem, lecz spekulatywna

\footnotetext{
${ }^{28}$ Ferguson (1906, 232 i n.). Więcej w: Faivre (2002, 126 i n.) oraz Breger (1984, 59).

${ }^{29}$ Eglin, oprócz tego, że związany był z hermetycznym dworem landgrafa i był uczniem Giordana Bruna (którego spotkał jeszcze w Zurychu, przed ucieczką do Niemiec), pozostawał również w kontakcie z Michaelem Maierem i Oswaldem Crollem.

30 Zob. wydanie krytyczne listu z zachowanego egzemplarza z Tybingi w: Kühlmann, Telle (2013, 1081 i n., nr. 161, w. 60-108).
} 
apokaliptyką przenikniętą duchem teozofii naturalnej oraz wiarą w nowe możliwości poznania materii i odnowę medycyny. Mit Helias artium chymicarum funkcjonował w tym właśnie nowym kontekście, łącząc rozbieżne z pozoru rejestry: mistyczno-kabalistyczny obraz proroka z tradycji judeochrześcijańskiej z ambicjami reformowanej chymii, medycyny i antyscholastycznej filozofii przyrody. Nieprzypadkowo „Chrystiana Rosenkreutza” manifestów różokrzyżowych łączy z nim bezpośrednie podobieństwo: „Fr. R.C” jako postać z Famy i Confessio byłby w tym przypadku twórczym rozwinięciem i konkretyzacja „,mesjasza alchemii”, co zasugerował na przykład Matt Goldish w swoim studium żydowskiego millenaryzmu (Goldish 2004, 21 i n.; zob. Faivre 2002, 130 i n.). Rozległość tych podobieństw i ich rozrzut w czasie wskazują, że mniej więcej od okresu reformacji apokaliptyka w Europie Środkowej zaczęła przechodzić głęboką mutację wraz z na nowo splecionymi kierunkami działań: przyroda, materią i laboratorium. Nowy typ wertykalnej apokaliptyki przyrodniczej towarzyszył zarówno rekonfiguracji relacji społecznych, jak i poszerzaniu spektrum eksploracji oraz eksperymentowania (Moran 2006). Wraz z nia w nieunikniony sposób transformację przechodził także tradycyjny millenaryzm, wypełniający się spontanicznie, początkowo na swoich marginesach, hybrydyzującymi treściami i wyobrażeniami, co widać już choćby w postępującym nakładaniu się obrazów Eliasza chymii i Eliasza biblijnego. Wyjaśnienia wymaga jednak najpierw, jak ta nowa apokaliptyczna formacja i mentalność - „chymiczna religia” paracelsystów - uczestniczyła w procesie stopniowego wytwarzania gruntu dla pracy nowoczesności. Ma to związek zarówno z historią nauki, jak i problematycznością tak zwanej tezy o sekularyzacji.

\section{Paracelsyzm jako hybryda: chrześcijańska religia przyrody, ontologia wyrażania i zarysy nowożytnego panteizmu}

Kluczowe znaczenie ma dostrzeżenie dwóch nierozerwalnie sprzężonych momentów w obrębie formacji paracelsjańskiej w jej rozwoju aż po XVII wiek, które jedynie wydają się całkowicie przeciwstawne, a nawet sprzeczne, ale mają swój początek u samego Paracelsusa: moment spirytualistyczny i moment materialistyczny. Sposób, waki sa one przemieszane, $z$ jednej strony wskazuje, w jakim sensie sam paracelsyzm był już ruchem nowoczesnym i jakie było jego polityczne znaczenie, z drugiej zaś, co to dokładnie znaczy, gdy mówimy o specyfice wczesnonowożytnej apokaliptyki przyrodniczej jako przejawu tego sprzężenia. Ambiwalencja idei i praktyki Paracelsusa, tego „prawdziwego Fausta epoki” (Suchodolski 1963, 378), którego pisma były wówczas - jak trafnie zauważa Hacking (2002, 
96) - bardziej wpływowe niż dzieło Kopernika, skłaniała historyków do przypisywania mu sprzecznych charakterystyk i do przeciwstawnych ocen w kwestii jego roli w historii wczesnej nauki: dla jednych zarówno on, jak i formacja paracelsjańska to fenomeny jeszcze przednowoczesne i wsteczne, dla innych już nowoczesne i postępowe (np. Kurt Goldammer contra Walter Pagel, zob. Prinke 2014, 302 i n.). Brian Vickers (1984, 127 i n.) broni na przykład konserwatywnej tezy, iż ekstremalna wersja magicznej „reifikacji” - jak to nazywa języka, myśli i wyobraźni z ontologicznym zamazaniem granicy między materialnym a duchowym u Paracelsusa była beznadziejnie archaiczna i poznawczo szkodliwa (w szczególności w zderzeniu z mechaniką kartezjańska), a więc skazana na porażkę. Być może to ostatnie jest prawdą, ale to pierwsze jako domniemana przesłanka - już nie. Takie postawienie problemu należy uznać za bardzo mylące, ponieważ operuje ono bezużytecznym artefaktem - ahistorycznym i naiwnie dychotomicznym rozumieniem nauki oraz nowoczesności (zob. np. Henry 2008; Newman 2009), a także systematycznie nie doszacowuje głębokości ideologicznego „efektu paracelsjańskiego” w XVI i XVII wieku, daleko poza widocznymi jego przejawami w postaci bezpośrednich polemik. Efekt ten uruchomił szereg wczesnowoczesnych batalii ideologicznych i dyskursów, których wynik niezależnie od losów paracelsyzmu - jeszcze dobitniej pogrążył katolicką scholastykę z jej arystotelesowskim rozumieniem materii.

Moment spirytualistyczny widoczny jest u Paracelsusa już w jego gwałtownym odrzuceniu wszystkich instytucjonalnych Kościołów, które pogardliwie nazywał „Mauerkirchen” (Kościołami murowanymi), wraz z ich kultem, obrzędami, dewocją i egzekwowaną władza, i w przeniesieniu całej duchowości chrześcijańskiej na poziom wewnątrzjednostkowy, co wyznaczyło trajektorię prowadząca do późniejszych form radykalnego protestanckiego pietyzmu i nowoczesnego bycia i świeckim, i pobożnym (Latour 2011, 53). Wrogiem był dla niego nie tylko katolicki kler i papież jako jego reprezentant, ale z czasem także Kościoły poreformacyjne z Lutrem i Zwinglim na czele: wszelkie uczęszczanie na nabożeństwa kościelne uważał za idolatrię i w De secretis secretorum theologiae (ok. 1531) tym, którzy słyszą od kaznodziejów „Głosimy ewangelię” i „Nauczamy Słowa Bożego” radzi krótko: „Das glaubent nit”, „Nie wierzcie w to” (cyt. w: Gilly 1994, 427), niestrudzenie ostrzegając - jak Franck, Weigel i inni spirytualiści - że fałszują oni naukę Chrystusa, niszcząc w ludziach „wewnętrzne Słowo”. Jest to oczywiście typowy wczesnonowoczesny symptom walk o nową formułę religijną jako realne kwantum władzy. Chrześcijaństwo Paracelsusa było proste, pacyfistyczne i ewangeliczne, oparte na idei wewnętrznego odrodzenia i duchowej obecności Chrystusa oraz mistycznej teologii „ciała zmartwychwstania" z pism św. Pawła, bez żadnej roli odgrywanej przez mediację Kościoła (skoro Duch Święty działa całkowicie poza nim). Jego wizja odnowionego chrześcijaństwa opierała się na solidarności, powszechnej równości ludzi, darmowym leczeniu we wspólnych 
szpitalach, zniesieniu dziedziczenia bogactwa przez dzieci, wspólnej własności ziemi i dzieleniu dóbr jak w Dziejach Apostolskich 2, 44-46. Pracował wśród biedoty, więc mógł pytać, wyobrażając sobie tę nową rewolucyjną konfigurację władzy do zrealizowania nawet w topografii szpitala: „Czym ty jesteś, szlachciuro? Czym jesteś, mieszczuchu? Czym ty jesteś, kupczyku? Czy twój brud śmierdzi mniej niż brud biedaka? (...) Coś ty zrobił, że nie jesteś taką samą krwią, kośćmi i ciałem jak biedak, i że tak samo nie będą cię jadły robaki, nie obrócisz się w pył i proch, z powrotem w ziemi?” (Paracelsus 1965, 426; cyt. też w: Wollgast 1993b, 657).

W sposób naturalny późniejsi alchemoparacelsyści czytający jego krążące wyłącznie w rękopisach pisma teologiczne słusznie kojarzyli je z innymi nurtami radykalnego poreformacyjnego spirytualizmu - Dencka, Huta, Hoffmana, Schwenckfelda czy Francka i utrzymali tę radykalną linię aż po początek XVII w. (część z nich była zdeklarowanymi schwenckfeldystami), inni natomiast, skupieni na praktyce medycznej i farmacji, byli nimi najwyraźniej zakłopotani lub próbowali łagodzić ich wymowę (Gilly 1994, 435 i n.). To spirytualistyczne powinowactwo myślenia Paracelsusa i radykalnych idei anabaptystycznych ułatwiło mu oczywiście przejście na stronę rewolty górników i chłopów w Salzburgu w 1525 r., a także ciagłe buntownicze potępianie struktur świecko-religijnej władzy i kościelnego wyzysku ubogich (nigdy nie służył też na żadnym dworze). Tuż przed ucieczką z Salzburga napisał jeszcze niezależny, reformatorski pamflet De septem punctis idolatriae cristianae, atakujący katolicką obrzędowość jako masową idolatrię. Religijność paracelsjańska w XVI wieku, w swoich charakterystycznie indywidualistycznych przejawach zjawisko już w zasadzie nowoczesne, kontynuowała tę spirytualistyczną trajektorię z kulminacją w ostatnich dekadach XVI wieku, kiedy Paracelsus zaczął przybierać w jej ramach format proroka nowej, oczekującej Eliasza nauk chrześcijańskiej religii chymicznej (Gilly 1994, 449 i n.). Oznacza to, że lokalna idea wyraźnie natrafiła na falę nośną działających szerzej przemian społecznych i uległa wzmocnieniu właśnie wzdłuż osi religijnej, kluczowej politycznie.

Chymiczne chrześcijaństwo Paracelsusa jest istotnie intrygujące, ale na pewno nie pod takim względem, który dla historyków takich jak Vickers świadczyłby o archaiczności i szkodliwości jego wpływu na rodzące się nauki. Moment materialistyczny, „materializm Paracelsusa” (Vickers 1984, 129), nie jest tu bowiem wynikiem godnego pożałowania ekscesu renesansowego neoplatonizmu, który przypadkowo zabłąkał się do warsztatu medyka albo kowala, co skutkowało patologiczna materializacja tego, co „duchowe” i rozlaniem się myślenia magicznego poza przykry i wstydliwy obszar przesądu. Jest to raczej konkretny historyczny przejaw zachodzącej reorientacji działań, przesuwającej rozmaite praktyki i ich efekty na pola wcześniej im obce. Mówiąc najprościej, paracelsjańska religia chymiczna jest modelową hybrydą w sensie latourowskim, a właściwie specyficzną fazą wczesnonowoczesnego procesu hybrydyzacji praktyk i idei. To, co budzi odrazę u Vickersa 
i takich klasyków historii nauki jak Rupert Hall, a zniechęcenie u Hackinga, to właśnie ekscentryczny moment empiryczno-materialistyczny, którego nie można w żaden zadowalający sposób wyrwać z jego splątania z momentem religijno-spirytualistycznym. Ale, co nie zaskakuje, już Siegfried Wollgast (1993b, 649), spoglądając z bliższej krytyce marksistowskiej pozycji, nie widzi tu nic zaskakującego ani wstecznego z perspektywy specyfiki nowożytnych praktyk, jeśli zwrócić uwagę na to splątanie, egzotyczną „nową jedność", jako specyficzny wytwór wyłaniającej się dość szybko zmienionej orientacji. Nieprzypadkowo materialistyczny aspekt dochodzi do głosu właśnie na pozornie opozycyjnym do niego biegunie, co jest widocznym przejawem tego przemieszczenia układu odniesienia: w obszarze teologii (jeśli uznamy to w ogóle za odpowiednie określenie w przypadku Paracelsusa).

Newralgicznym punktem jest oczywiście materia i jej pierwotność, czyli prima materia jako byt ontologiczno-polityczny, z czego zdawał sobie sprawę już Bloch (1985b, 222 i n.). Dla Paracelsusa nie jest ona ani gotowym „tworzywem w ruchu” tradycyjnego materializmu, ani scholastyczną bierną „możnością”, która jest aktualizowana, lecz nieustającą czynnością, siłą albo ekspresją, które wiąże on z kreacyjnym wypowiadaniem (Logosem) z prologu Ewangelii Jana. W swym dojrzałym Opus paramirum wprost utożsamia tę materię pierwszą (którą nazywa też yliastrum - iliastrem, Mysterium Magnum, Chaosem, „erste yle” albo „materia ostateczną”, materia ultima ${ }^{31}$ z boskim „Fiat” ${ }^{32}$, co jest nie do pogodzenia z całą ortodoksyjna teologia chrześcijańska, ponieważ oznacza to, że materią pierwszą jest po prostu Chrystus! Wprost pisze o niej, że jest poczatkiem (anfang) i od zawsze „była w Bogu/u Boga”, bei got a więc nie może być rozumiana jako stwarzana albo „rodzona” - jest uniwersalną moca ekspresji i posiada status boski. Dopiero wtórnie ta moc działania, w której „wszystko spoczywa ukryte”, wyraża się za sprawą immanentnych czynników - „wulkanów” i „archeuszy” jako ,wewnętrznych alchemików” przyrody - w swoich wytworach, w materii „mineralnej” i „metalicznej”, czyli staje się „ciałem”, „uchwytnym” (greiflich), które ulega wciąż dysolucji i jest polem dalszych przekształceń ${ }^{34}$. Ta siła ekspresji działa poprzez

31 Paracelsus nazywa tak materia prima w swoim wczesnym De mineralibus (Paracelsus 1930b, 34). Zob. Pagel (1961, 119; 1982, 112).

32 Paracelsus 1925, 48: ,dieweil aber prima materia mundi fiat ist gewesen, wer wil sich unterstehen das fiat zuerkleren?’” Zob. Pagel (1961, 118 i n.).

33 Paracelsus 1930b, 34: „Nun ist das erst gewesen bei got, der anfang, das ist ultima materia...” Już we wczesnym tekście medycznym z lat 20. XVI w. Paracelsus (1929, 316) używa tego samego wyrażenia, „bei got”, stwierdzając, że na początku wszystkie „rzeczy” były „niewidzialne u Boga”, tworząc następnie swoje widzialne, fizyczne formy. Wyrażenie to jest oczywiście wzięte z prologu Ewangelii Jana (1, 1), stwierdzającego, że „Słowo było u Boga ( w laboratorium, ale jako pozaczasowy iliaster-Chaos-Fiat jest warunkiem zaistnienia czegokolwiek empirycznego.

${ }^{34}$ Paracelsus 1933b, 549: „Yliastrum ist die erste materia, daraus sal, sulphur und mercurius geschaffen sind. dadurch verstehen wir, wie das verbum Fiat materialisch, greiflich und ein leib ist worden, darinnen nun alle praedestinata stecken und verborgen ligen..." 
„nasiona” (samen), czyli zawarte w materia prima niecielesne ośrodki produkcji rzeczy naturalnych (będące więc ich własnymi „materiami pierwszymi”), trochę jak immanentny przyrodzie stoicki logos spermatikos ${ }^{35}$. Paracelsus nie potrafi myśleć o naturze, abstrahując od dynamicznego generowania („rodzenia”, gebären), zawsze przekraczającego wszystkie swoje przejściowe wytwory, a materia-moc nigdy nie staje się u niego ani bladą potentia „papistów”, ani czymś na kształt zbioru zderzających się atomów, i nawet gdy pisze o duchu, nie znika ona zakryta ideologicznym ekranem teologii. Materia prima rozumiana jest jako pierwotna, wytwórcza aktywność, a Bóg-chymik jedynie jako Separator, co całkowicie odwraca tomistyczną metafizykę i usuwa z gry doktrynę creatio ex nibilo. Świat paracelsjański to świat sił i ekspresji, które sprzęgają się ze sobą, wchodzą w alianse albo się nawzajem hamuja i wygaszają: nie można być jego biernym obserwatorem - nawet ludzkie wyobrażenie albo myśl jest u Paracelsusa organicznym układem sił, tak jak są nim dojrzewanie owoców, wytrącenie soli albo choroba płuc. Niepostrzegalne zmysłowo „nasiona” działaja jako wytwórcze, multiplikujące siły i dlatego, nawet gdy Paracelsus utożsamia je ze Słowem z J 1, 1-3, patrzy na przyrodę nie jak skryba wpatrujący się w tekst, który ma podziwiać i kopiować, ale raczej jak zaradny rolnik, lekarz albo piekarz, który bez przerwy uczestniczy w grze tych sił i zaprzęga je do chwiejnej współpracy, co zresztą łatwo zepsuć. Na przykład lekarz prowadzący leczenie jest porównany do czynników powodujących wzrost roślin - jest „,innym archeuszem”, der ander Archeus, czyli naturalną siła, jak sam lek jest „,nasionem” (Pagel 1982, 110). Nic dziwnego, że Bóg bezpośrednio wyraża się teraz również w rudach metali, solach, płynach i gazach, a sam Chrystus-Logos zaczyna przypominać uniwersalny katalizator albo piekarski zakwas, tyle że w skali kosmicznej.

Typ witalistycznego panteizmu, który tu się zarysowuje (Goldammer 1953, 95, pisał o „witalistycznym monizmie” Paracelsusa, a Jane Bennett 1997, 2, nazywa to „schrystianizowaną wersją animizmu”), znacząco różni się od takich jego form, które inspirowane były wcześniej średniowiecznym „wysokim” neoplatonizmem chrześcijańskim, od Eriugeny po Mikołaja z Kuzy, odwołujących się do 1 Kor 15, 28 oraz Kol 1, 16-17. Te ostatnie zachowywały bezpieczną transcendencję Boga, usztywniając podział na materię i formę, nazywając Boga - obecnego we wszystkich swoich wytworach - jedynie forma omnium („forma wszystkiego”) albo forma formarum, przy jednoczesnym teologicznym wybiegu (i paradoksie) określania tego Boga jako mocy „poza bytem” i „poza formą, nibil (choć oczywiście nie w prywatywnym znaczeniu neoplatońskiej materii), co robi na przykład Eriugena. Jest to klasyczna postać ideologicznej gwarancji udzielonej transcendencji i fundament każdej ortodoksyjnej teologii politycznej: to „nibil’ względem bytów ma maksimum suwerennej i stwórczej władzy, a więc wzniosły paradoks - Bóg-Nibil

35 Paracelsus 1930b, 34: „als ein frucht, die ein ander frucht sol geben, die selbige hat ein semen: der sam ist in prima materia". 
wabsolutnej opozycji do materii-nibil - tuszuje tu nadal teologiczną alienację przyrody i materii. Paracelsus, pomimo innych rozproszonych teologicznych stwierdzeń, które zdają się bliższe ortodoksji, należy do linii heterodoksyjnego panteizmu - kulminującej w myśli Giordana Bruna ${ }^{36}$ - która rozluzowuje podział na materię i formę lub odwraca ich hierarchię, uhistoryczniając formy, wprost utożsamia Boga (Chrystusa) z dynamiczną pra-materia i systematycznie zamazuje ontologiczna przepaść między nim a przyroda. Ten typ wyobraźni filozoficznej można bez wątpienia zidentyfikować jako pierwszy etap nowożytnej rewolty przeciwko logicznej koncepcji bytu w kierunku koncepcji historycznej, która jest warunkiem sine qua non szeroko rozumianego materializmu (zob. też Bloch 1985b, 223).

W przywołanym wywodzie z De Mineralibus Bóg jest „Artysta” (Kunstler), ale ten „Mistrz”-Chymik (Meister) zdaje się nie mieć w sobie nic ontologicznie transcendentnego jest natura w trybie najwyższej ekspresywności i twórczej mocy, generującej z siebie formy„nasiona”: „on sam tylko jest wszystkim we wszystkim; jest pierwsza materią (materia prima) wszystkiego; jest ostateczna materia (ultima materia) wszystkich rzeczy; on jest wszystkim, co jest" ${ }^{37}$. Materia-Chrystus-Fiat (Mysterium Magnum) Paracelsusa pulsuje od wewnętrznych sił, kiełkuje, przekształca się, różnicuje, dzieli i owocuje. Życie tego Boga objawia się w rośnięciu kryształów, pszczelich ulach, wichurach, ruchach planet i krążeniu krwi, w wyobraźni i widzeniu, dlatego sam stosunek do przyrody ulega tu nowemu religijnemu ukierunkowaniu: metalurgii, farmacji czy botanice bliżej do tajemnic boskich niż wszystkim studiom teologicznym razem wziętym, a sztolnie górnicze albo laboratoria to lepsze miejsca do dogłębnej kontemplacji natury Boga niż kościoły i klasztory. Na frontyspisie Opera Omnia (1682) Jana Baptysty van Helmonta widzimy na przykład chymika przypatrującego się pracy rolników i górników wśród pracy przyrody: dymiącego wulkanu, słońca, kwitnących roślin i morskich zwierzat, a jego laboratorium graniczy z uprawnym polem. Laboratoryjny proces alchemiczny jest jakościowo tym samym, co działania przyrody, osad w retorcie ma swój geologiczny odpowiednik w minerałach kopalnych. Już choćby w tym punkcie widać, jak bardzo klasyczny filozoficzny ideał theoria - poznania kontemplacyjnego sprzężonego z ideologia transcendencji Absolutu - uległ deprecjacji na rzecz badania konkretnych zjawisk przyrody jako przedmiotów sztuk uznawanych wcześniej za niższe, jak metalurgia, botanika

\footnotetext{
${ }^{36} \mathrm{O}$ ile mi wiadomo, jako pierwszy na tle tej tradycji umieścił Paracelsusa Pagel (1961, 134; 1982, 227 i n.), zdaniem którego Paracelsusa należy widzieć w kontekście ontologii materii pierwszej autorstwa ibn Gabirola (Awicebrona) - jednego z ważnych źródeł średniowiecznego heterodoksyjnego panteizmu za pośrednictwem filozofii potępionego w 1210 r. Dawida z Dinant. Pagel (1982, 231), być może słusznie, stwierdza, że ta spekulatywna tradycja jest filozoficznym źródłem utożsamienia przez Paracelsusa Chrystusa i materia prima. Wcześniej szeroką linię arabskiej „arystotelesowskiej lewicy” (wraz z Awicebronem) i jej wpływu na „AntyKośció’' zarysował Bloch (nie wspominając Paracelsusa) w swoim słynnym eseju Avicenna und die aristotelische Linke z 1952 r. (Bloch 1985a, 479-546).

37 Paracelsus 1930b, 34: „er ists allein, alles in allem, er ist rerum prima materia, er ist rerum ultima materia, er ist der alles ist'.
} 
czy rolnictwo. Religijno-materialistyczny panteizm, wbrew opinii Vickersa, nadawał się na hybrydowy nośnik tego przesunięcia równie dobrze jak znacznie późniejszy filozoficzny program Bacona i ma także swoje radykalne polityczne znaczenie, o wiele większe niż średniowieczne ruchy heretyckie.

Jest oczywiste, że tego typu hybrydyzacja, działając globalnie, nie tylko nasyca afektem wczesne praktyki eksperymentalne, ale także silnie modyfikuje formy religijności, które się z nimi sprzęgaja: kształtuje się apokaliptyczna religia przyrody jako trzeci biegun obok ortodoksji katolickiej i protestanckiej. Jak każda hybryda zdaje się o na pełna niespójności, nieciagłości i nie pasuje do żadnego z tych jawnych biegunów, mimo że pozostaje z nimi w konfliktowych relacjach, tworząc w samym centrum świata protestanckiego (Tybinga, Marburg czy Kassel) takie religijne chimery jak alchemoparacelsyzm i wspomniane „,widmowe” różokrzyżostwo.

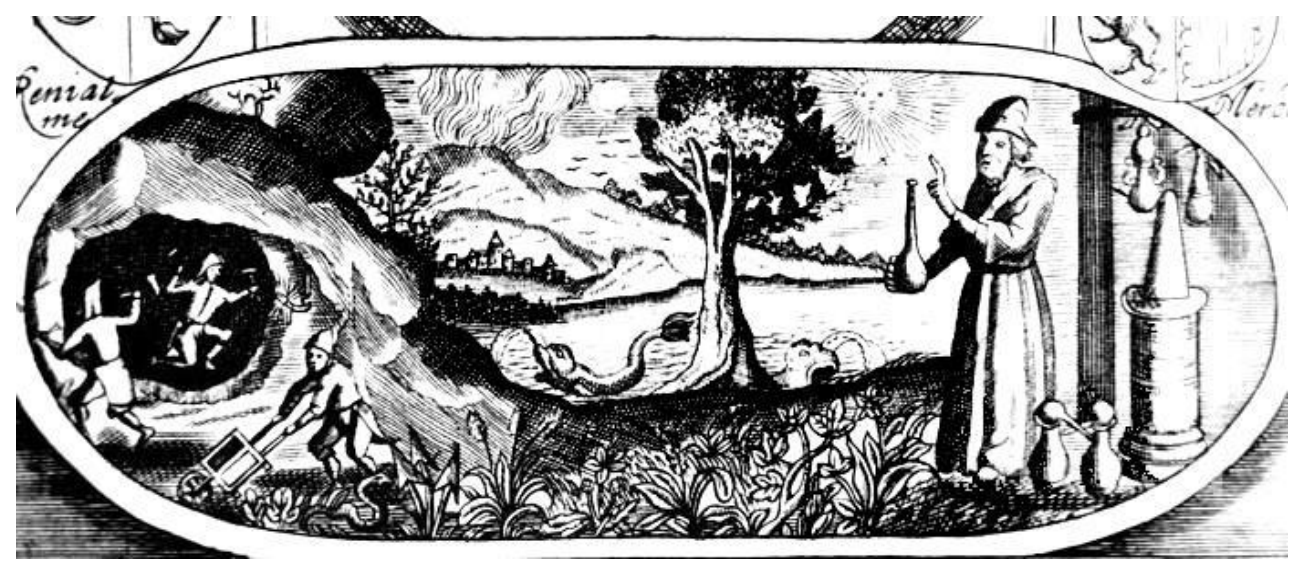

Dolny fragment frontyspisu z Opera Omnia Jana Baptysty van Helmonta (Frankfurt 1682)

Chimery te nie są archaicznymi pozostałościami starej epoki, ale raczej immanentnym warunkiem formowania się nowej konfiguracji doświadczania - zachodzi poprzez nie renegocjacja, również polityczna, wcześniejszych relacji między teorią i praktyka, dlatego są one zarazem medium kryzysu i nowo powstałym polem, na którym moga też pracować typowe dla nowoczesności procedury puryfikacji (Latour 2011). Jednym z ostatnich prominentnych przedstawicieli tej religii przyrody w końcu XVII wieku był w ukryciu Newton, który stanowi poważny problem dla konserwatywnej historiografii nauki nie z racji głębokiej religijnej herezji, ale ze względu na fakt, że miała ona jako motywacja - jak w przypadku alchemoparacelsystów - fundamentalne znaczenie dla prowadzonych przez niego studiów i eksperymentów (zob. np. Dobbs 1991; Woszczek 2009; Henry 2008). Przykładowo, powiedzenie w stylu kartezjanistów czy późniejszych mechanicystów, że materia jako rozciagłość jest bierna albo oddzielona od ducha, było dla Newtona, który dogłębnie znał tradycję alchemoparacelsjańska, oczywistym fałszem, o czym jednak 
w Principiach świadomie milczy. Kilka lat po nich, w rozdziale o materia prima, „pierwszej materii wszystkich metali”, w swoim alchemicznym kompendium Praxis (Babson MS 420) nazywa ja za Philalethesem „Naturą” i definiuje jako „cielesnego ducha i ciało duchowe”, spiritus corporalis et corpus spirituale (transkrypcja w: Dobbs 1991, 297). Również sam aksjomatyczny, antyindukcjonistyczny sposób, w jaki wykłada fundamenty mechaniki w Principiach, jest raczej pitagorejski z ducha i dobrze odpowiada apokaliptycznej mentalności Newtona, ale też i współczesnym zwolennikom ,inteligentnego projektu” (Fuller 2009, 74 i n.). Na tym przykładzie widać wyraźnie, jak trudno bronić mitu „Rewolucji Naukowej”: praca puryfikacji nie była nigdy fundacyjnym wydarzeniem ani prostą sekwencja filozoficznych decyzji, dlatego nie ma żadnej sprzeczności ani obskuranckiego aliansu ze średniowieczem (Vickers) w stwierdzeniu, że nowoczesność miała swoją własna apokaliptykę jako religijno-społeczną ontologię odkrywania. Choć miała ona, owszem, niejednokrotnie ekscentryczne - z perspektywy późniejszych, „regularnych” ontologii pracy nauki - przejawy. Zaraz po ukazaniu się manifestów różokrzyżowych pojawił się na przykład w odpowiedzi druk Speculum Sophicum Rhodo-Stauroticum (1618) „Theophila Schweighardta” (pseudonim Daniela Möglinga, od 1611 r. lekarza, matematyka i astronoma na dworze landgrafa Hesji-Butzbach, przyjaciela Wilhelma Schickarda, Keplera i Andreae’i), w którym jedna ze słynnych rycin ilustruje ten typ nowej religijności (zob. komentarz Haslmayra z 1626 r. w: Gilly 1994, 460 i n.). Na górze zachodzi „Ergon” (Dzieło), które przypomina religijny czy magiczny rytuał z modlitwą o mistyczne oświecenie, zaś w głębi góry przebiega jednocześnie „Parergon” (Dzieło Towarzyszące), będące „fizjologia”" (Physiologia) - poznaniem praw i sił przyrody oraz laboratoryjnym eksperymentowaniem - która „im powszechniej jest uprawiana, tym większe da korzyści” (Schweighardt 1618, 12). Zachętom do studiowania mistycznej książeczki Tomasza à Kempis i modlitwy towarzyszy w tekście fascynacja ukrytymi siłami, „nasieniem” (sperma), zasadzonymi przez Stwórcę w każdej rzeczy, „ein verborgene Göttliche wirckende Krafft' (Schweighardt 1618, 17), dzięki któremu one „wzrastają” i to właśnie te ukryte siły, a nie same widzialne substancje i ciała, są przyrodą: „I to się nazywa Natura, reguła i miarą wszystkich nauk, służącą Boga i panią wszystkich ludzkich tworów, matką wszystkich zwierząt, roślin i minerałów, jasnym blaskiem boskich płomieni” (Schweighardt 1618, 17).

Piętrzące się tu niespójności i napięcia widoczne są na pierwszy rzut oka. Sekrety przyrody, jej wytwórcze siły i możliwości ich opanowania są obiektem fascynacji („patrzeniem lewym okiem” w czas i przestrzeń), ale mistyczna kontemplacja i pogłębione religijne życie, „patrzenie prawym okiem” w wieczność, ma zabezpieczać przed wysunięciem jej na pierwszy plan (Schweighardt 1618, 13: „,nie używaj tego inaczej niż tylko jako dzieła towarzyszącego, w przeciwnym razie lepiej byłoby dla ciebie, gdyby uwiązać ci kamień młyński u szyi i utopić na dnie morza”). Religijny rytuał modlitewny i ofiarny na górze, Ergon, 
nie przypomina żadnego kościelnego nabożeństwa, ani katolickiego, ani protestanckiego, lecz raczej dziwną barokową mutację starożytnej pogańskiej teurgii, będąc „największą i przewodnią sztuką i nauką” (Schweighardt 1618, 18: „die gröste und fürnembste Kunst und Wissenschaft”, sic!). Góra, na której zachodzi ofiarowanie i „naśladowanie Chrystusa”, ma formę czaszki, jest Golgotą (= Calvaria, „czaszka”), ale nie ma na jej szczycie żadnego krzyża i, co może niepokoić chrześcijańskiego ortodoksa, równie dobrze mógłby to być rytuał jakiegoś żydowskiego kabalisty. Sekrety tworzenia są co prawda odkrywane i wydzierane przyrodzie, ale zarazem miałby to być przejaw ściśle mistycznej, na nowo zreformowanej pobożności. Przyroda ta dysponuje wprawdzie potężnymi siłami i jest majestatyczna twórczynią wszystkiego, ale zarazem jest „służącą Boga”, eine Dienerin Gottes. Chymik jest pokornym współpracownikiem Natury w jej procesach obiegów i oczyszczania (balia z woda pod gołym niebem po lewej),

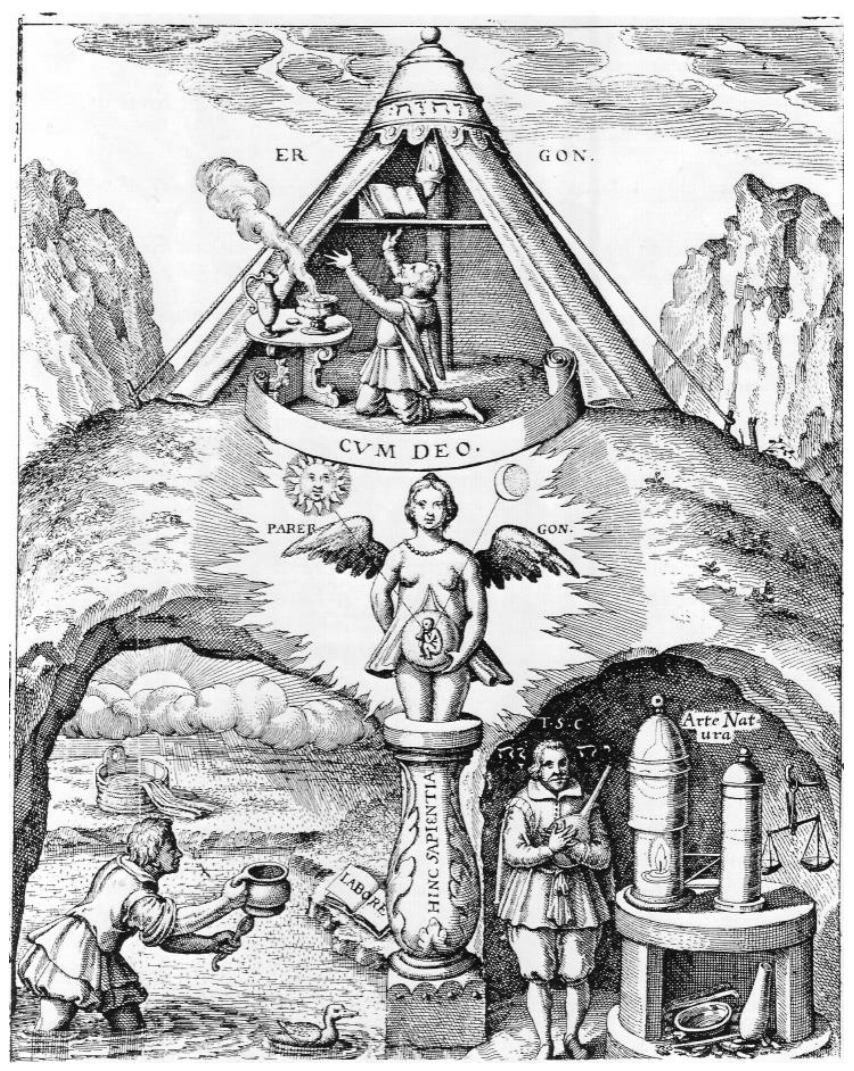

Jedna z trzech rycin ze Speculum Sopbicum Rhodo-Stauroticum Daniela Möglinga

(Frankfurt nad Menem?, 1618)

ale również suwerennym władcą zamkniętego laboratorium (po prawej), przeprowadzającym technologiczne operacje zgodnie ze swoimi własnymi celami. Cała „fizjologia” jako studia i operacje chymiczne skupiona jest na materii i czasie, ale chymik ma kierować się fundamentalną dewizą: „poznaj samego siebie!”, gdyż fizjologia ma też swój wyraz w duszy 
jako wiecznym „centrum i obrazie Boga”. Radykalny pietyzm chce tu wchłonąć cała chymię; ale ta chymia ma z kolei stanąć na własne nogi, ignorując „bezużyteczne i próżne kłótnie” nad tekstami Arystotelesa albo Platona na uniwersytetach, gdyż „tam nie prowadzi się eksperymentów naturalnych (Naturgemessene experimenta), nie odwołuje się ani do argumentów intelektualnych, ani świadectw zmysłów (auff intelectualles oder sensuales rationes)" (Schweighardt $1618,17)^{38}$. Te paradoksy i niejasności można by bez końca mnożyć: sama ta rycina jako dokument stanu ducha i mentalności to jedna wielka hybryda, która mówi o wczesnej nowoczesności więcej niż będące świadectwem zaawansowanej już puryfikacji, późniejsze o dwie dekady Medytacje Kartezjusza.

Efekt takiej ewolucji paracelsyzmu jest jednak czytelny: nowa apokaliptyczna religia przyrody, chrześcijaństwo chymiczne, koncentruje się wokół apokalupsis dokładnie w tym sensie, że sekrety materii znajdują się w centrum jej zainteresowania - stają się powoli bardziej nawet fascynujące niż „tajemnice niebiańskie”, a apokaliptyczną księgą zostaje sama objawiająca się przyroda, co zmienia także model pobożności, przesuniętej teraz w stronę laboratorium i obserwatorium. W wydrukowanym anonimowo w antologii Philosophia Mystica w 1618 roku tekście Introductio Hominis autor stwierdza nawet, że Chymia jako najwyższa ze sztuk „daje pełne poznanie nie tylko przyrodniczych, ale i boskich spraw” ([Siebmacher] 1618, 231)! Paracelsus sugeruje, że w mistycznym uniesieniu dusza (gemüt), bezgraniczna jak dla Heraklita, może jednoczyć się z materia pierwsza-Chaosem, wieczna ,jak Bóg i niebo” (Paracelsus 1931, 383; zob. Pagel 1979, 69), co - brzmiąc po stoicku - jest nie do pomyślenia dla tradycyjnej chrześcijańskiej mistyki, ale tu pojawia się zupełnie naturalnie w wyniku utożsamienia tej materii z Fiat-Logosem. Religijność ta oscyluje wokół wyobrażeń panteistycznych, zbliżając się do nich lub je subtelnie stymulując i powodując, że Natura wyrasta nagle obok Boga do roli samodzielnej aktorki w grze o władzę, co uruchamia też od razu kryzys polityczny związany z ruchami obojga graczy na epistemologicznej planszy.

Obraz takiej hipostazowanej Natury oglądany jest „stereoskopowo”, co narusza teologiczny status quo wypracowany przez scholastykę: wysiłek praktyczny skupia się na programowej eksploracji materii i manipulacji dostępnymi procesami fizycznymi, a zarazem wyobraźnia ontologiczno-religijna obsesyjnie koncentruje się na causae abditae, ukrytej stronie przyrody - jej siłach wytwórczych, wewnętrznej dynamice, niejawnych regułach, prawach działania, które mają być jej „tajemnym alfabetem” (są to „Arcana” Paracelsusa, zob. Pagel 1979, 62 i n.) i które także podlegają eksploracji. Zaburzenie chrześcijańskiego antymonizmu i jego politycznego bezpiecznika w postaci bezwarunkowej transcendencji Boga powoduje też, że scholastyczna maszyneria teorii analogii bytu i abstrakcji przestaje działać

${ }_{38} \mathrm{Na}$ temat siedemnastowiecznej pogardy dla uniwersytetów jako ośrodków władzy nad reprodukcja nieaktualnych form wiedzy i w kwestii tworzenia alternatywnych struktur towarzystw naukowych zob. np. Shapin 2000, $117 \mathrm{i} \mathrm{n}$. 
i na pierwszy plan wysuwa się materialistyczna ontologia wyrażania-ekspresji, kulminująca w końcu u Bruna, Boehmego i - jako racjonalistyczny materializm - u Spinozy. Widać to już w samym języku paracelsjańskiej chymii, który funkcjonuje, nie respektując zasady abstrakcji i definiowania przez genus proximum et differentia specifica, co odzwierciedla zupelnie inna, „artystyczna” czy produkcyjną ontologię leżącą u podłoża jej kosmologii. Apokaliptyka przyrodnicza, w której nie ma efektywnej ontologicznej zasady mocnego transcendowania, generującej wyraźne poziomy hierarchii bytu i oddzielającej duszę i język od dynamiki przyrody, nie może nawet wytworzyć Lockowskiej idei jakości pierwotnych i wtórnych, gdyż sens „bycia ukrytym” jest w niej radykalnie odmienny niż w późniejszym kontekście empirystycznym - nie pokrywa się z sensem „niepoznawalności” czy „empirycznej niedostępności” - co sprawia, że raczej prowokuje do eksploracji i spekulacji niż zniechęca przez sceptycyzm (jest to też „pragmatyczna” składowa wkładu magii naturalnej we wczesna naukę, zob. np. Henry 2008). W takiej kosmologii świat rzeczywiście nie może nigdy zostać po weberowsku odczarowany, choćby w końcu jego sekrety były coraz lepiej poznawane, językowo wyrażane i użyteczne technicznie, ponieważ działa on na zasadzie niekończącej się ekspresji, mutacji i amalgamacji, zyskujących osobliwie religijny nimb (por. Bennett 1997). W tej sytuacji, nawet gdy używana jest średniowieczna metafora „księgi przyrody” i jej „alfabetu”, nie znaczy ona i nie może znaczyć tego samego, co wcześniej - otwiera się tu pole dla nowego typu mistyki (zob. Pagel 1979), pozostającego w gwałtownym konflikcie z ortodoksyjną mistyką i pobożnością, czym zajmę się w drugiej części. Również ona jest zdumiewająca hybryda: skoro ukryte życie Chrystusa można wyśledzić nawet w krystalizacji soli albo owocowaniu roślin, pod znakiem zapytania stoi maszyneria teologiczna zasilająca tradycyjne chrześcijaństwo.

Ten typ apokaliptyki zorganizowany jest wokół osi wertykalnej i wyraźnie odsuwa na drugi plan oś eschatologiczna, a wymiar głębi przyrody i jej warstwowych ekspresji staje się dominujący, gdy ujawnienie jednego jej sekretu uświadamia niezliczoną wielość kolejnych, jeszcze głębszych. Apokaliptyka ta była wczesnonowożytną mutacją apokaliptyki starożytnej, paradoksalnie stanowiąc, co zauważył już kiedyś Schelling $\left(1927,311\right.$ i n.) ${ }^{39}$, wewnętrzną tendencję samego chrześcijaństwa, nieobecną w myśli greckiej: jej szerokie treściowe zasoby stanowiły arabska alchemia, żydowska kabała i hermetyzm (zob. np. Walton 2015), ale

\footnotetext{
39 Schelling słusznie zauważył, że chrześcijaństwo zrobiło z przyrody tajemnicę, medium sekretów, które mają wyrażać coś głębszego - sama w sobie nie będąc boska, przyroda miała być znakiem czegoś boskiego, co doskonale współgra z centralnym tematem räąîn żydowskiej apokaliptyki. Poreformacyjny panteizm można zrozumieć jako radykalizację tej tendencji wewnątrz chrześcijaństwa przy jednoczesnym kwestionowaniu teologicznego dualizmu, czyli zasady generującej autorytet „czystego” (bezpośredniego) Objawienia. Daje to spontanicznie nową ontologię przyrody i języka, które zyskują zarazem głębię i nieprzejrzystość, prowokując jeszcze większą fascynację. Jest to aspekt tego, co Foucault (2000, 53 i n.) nazwał wczesnonowożytnym „systemem podwojeń”. Proces ten tłumaczy pozorny tylko paradoks nowoczesności: religijność panteizująca współwystępuje, a nawet zaskakująco wzmacnia trend ujmowania Absolutu jako Deus absconditus.
} 
specyficzna forma paracelsyzmu to jednak zradykalizowana w epoce reformacji wyobraźnia teologiczno-naturalistyczna. Zanim uruchomiona została w instytucjonalnej skali praca puryfikacji, która wytworzyła dojrzałych nowoczesnych (Latour 2011, 48-61), była to ukryta religia protestanckiej Europy i zarazem medium ideologicznego konfliktu zarysowanego wokół przyrody i Boga.

$\mathrm{Na}$ skutek pojęciowej dezynwoltury permanentnie myli się jednak apokaliptykę przyrodniczo-kosmologiczną z historyczno-eschatologiczną (mesjanistycznym millenaryzmem), nie dostrzegając, że te dwie osie - nawet jeśli czasem występują łącznie ciagle rodzą napięcia i w ogóle nie tworzyły ani nie tworzą żadnej spójnej formuły. Ta pierwsza oscyluje w końcu między kosmologia, „filozofią naturalną” i mistyka, skutecznie neutralizując chiliastyczny szał, albo - jak się to stało na przełomie XVI i XVII wieku - tak deformując millenarystyczne ideologie, że zaczęły działać odmiennie niż wcześniej i teolodzy Kościołów nie mogli już czasem rozpoznać w nich swoich zwyczajowych wierzeń. Ortodoksyjny luteranin taki jak Johann Gerhard (1582-1637) sporządził na przykład do celów polemicznych cała szczegółowa klasyfikację chiliastycznych herezji swoich czasów (Wallmann 1982), a i tak nie potrafił ujać ciagłych mutacji i skrzyżowań, w których mistyka, filozofia, polityka, interpretacja Biblii i rewolta społeczna zdawały się zagrażać poreformacyjnemu porządkowi (będącemu oczywiście iluzja). Millenarystyczny nurt paracelsyzmu był tylko jednym z takich skrzyżowań, ale nawet współcześni historycy religii zdają się nie doceniać wagi „wertykalnego” czynnika, który to skrzyżowanie stymulował, to znaczy apokaliptycznej ideologii sekretów materii i praktyk ich „ujawniania”, stabilizujących się z czasem niezależnie od eschatologicznych wierzeń, co napędzało w XVII wieku wczesną naukę, ale i wygenerowało także takie późne produkty uboczne jak rzeszę fanatyków „inteligentnego projektu”. Działanie tego czynnika spowodowało, że już nie tyle koniec historii, co sama nieprzejrzysta przyroda i materia z jej wymiarem głębi stały się szybko permanentnym problemem politycznym, co jest znakiem firmowym nowoczesności.

Jest to kwestia kluczowa, ponieważ autorzy tezy o sekularyzacji tacy jak Löwith czy Voegelin sami nie potrafili sobie najwyraźniej wyobrazić, jak możliwe było ukształtowanie się pracy nowoczesności i idei postępu (albo raczej upartej e k s p l o r a c ji) przy drugorzędnej, tylko pozornie znaczacej roli „horyzontalnej” eschatologii: w lokalnym medium rozproszonych, ale konkretnych działań społecznych, konfesyjnych starć i rozmytych, krążących dyskursów - od masowego drukowania religijnych broszur i pamfletów o niekontrolowanych treściach, często w tajnych oficynach (zob. np. Bubenheimer 1995, 1999) - poprzez proliferacje alternatywnych form organizacji społecznej (od lokalnych Kościołów po rozległe sieci korespondencyjne religijnych i naukowych dysydentów), aż po próby wytwarzania nowych leków i ciagłe podważanie uniwersyteckich autorytetów filozoficzno-teologicznych. Teza ta myli skutki i późne, zwłaszcza dziewiętnastowieczne, 
intelektualne wytwory z warunkami (warunkującymi praktykami), dopatruje się globalnej dialektyki tam, gdzie jej nie ma i sama operuje już w linearnej przestrzeni wyprodukowanej przez dojrzałą nowoczesność - jest wraz z Heglem, Weberem i Troeltschem jej samoodnośnym ruchem, czyniącym niewidzialnym swoje własne hybrydowe podziemie, która to niewidzialność ową przestrzeń funduje. Nic dziwnego, że nowoczesność Schmitta czy Voegelina wyskakuje jak nieprawomocna herezja-narośl z trzewi historii i przypomina im niedająca się do końca umiejscowić, demoniczną zjawę, która podobno pasożytuje na dostojnym, „zdrowym” judeochrześcijańskim mesjanizmie. Sa antynowoczesnymi reakcjonistami, którzy zarazem w pełni akceptują linearną autodefinicję nowoczesności (Latour 2011, 72) i potrafią myśleć tylko eschatologicznie, co usiłuje się nawet przedstawiać jako zaletę.

Ale studiowanie oderwanych idei $\mathrm{i}$ ich dialektyki niewiele tu pomoże, jeśli nie zrozumiemy, że były one zaledwie słabym odbiciem specyficznych praktyk deformujących w podzielonej Europie realne pola władzy obsadzone przez konkretne instytucje i siły polityczne. Historia tych praktyk jest mikrohistoria, na przykład konkretnych druków, ich sponsorów, oddanych czytelników i propagatorów, antyjezuickich działań na dworach, astronomicznych obserwacji, przygotowywania nowych typów leków i zainteresowania nowymi metodami rolniczymi, albo katedr medycyny i walk o nie, a nie globalną sagą o sekularyzacji. Nie bez powodu na przykład ktoś taki jak Carl Schmitt gardzi ową historią, ponieważ nie odpowiada na jego ponura, typowo konserwatywną obsesję chaosu grożącego gęstnieniem na osi czasu jako saeculum senescens. Gdy odrzucimy domniemaną wagę dyskursu eschatologicznego, wówczas pytanie o to, jak obserwacje komet, spory o „prawdziwa medycynę” i próby laboratoryjne wiązały się z bieżącą polityką, paniką moralną wokół spirytualistycznych ruchów społecznych albo interpretacjami Apokalipsy św. Jana, nie stanie się wcale egzotyczne, a wręcz przeciwnie: widoczne stają się decydująca rola podstawowego, lekceważonego wymiaru apokaliptyki oraz uruchomione przez niego zupełnie nowe konflikty o władzę, które mają niewiele wspólnego z jakimkolwiek mesjanizmem. Pożyteczne jest jednak przyjrzenie się, jak apokaliptyka przyrodnicza jako mentalność, religijna ontologia praktyk i konglomerat motywacji efektywnie zaburzyła tradycyjny chrześcijański millenaryzm - to znaczy, jak hybrydowy Eliasz nauk stał się na krótko, przed wojną trzydziestoletnia, protestanckim mesjaszem rewolucyjnego postępu.

\section{„Generalna reformacja świata” i „powszechna Przemiana”: paracelsjańska mutacja millenaryzmu}

Poreformacyjny millenaryzm wygląda prima facie klasycznie, ale im dokładniej mu się przyglądamy, tym wyraźniej widać jego rosnącą niestabilność: rozwija on z czasem wątki, 
które przed reformacją były marginalne lub traktowane jako podejrzane i dość szybko ewoluuje na swoich obrzeżach w kierunkach, które stymuluja ideologię „reformy nauk”, w szczególności „Wielką Instaurację” Bacona (Webster 2002). Poznanie tradycyjnie eschatologicznych sekretów zaczyna się po prostu mocno rymować z poznaniem sekretów przyrody i następnie jest przez te ostatnie redefiniowane, a równocześnie walki konfesyjne stają się nierozdzielne od polityki wiedzy, której węzłami są uniwersytety i stowarzyszenia naukowe. Religijna logika immanencji przejęła w rozmaitych kluczowych miejscach częściową kontrolę nad transcendentnym cięciem typowym dla mesjanizmu, co nie wymagało żadnego dziejowego zniesienia ani inwersji na drodze uprzedniej laicyzacji społeczeństw, „terroru mechanicyzacji” ani nadejścia Woltera i Condorceta. Alchemoparacelsyzm lokalnie zmieniał dziejowy pesymizm w optymistyczną eschatologię opartą na entuzjazmie wiedzy i praktyki.

Głównym źródłem opartych na „proroctwie Eliasza” spekulacji chiliastycznych w szerszych kręgach luterańskich, wykraczających poza ezoteryczną subkulturę, była z pewnością wspomniana praca Melanchtona Chronicon Carionis. Odwołując się do schematu czterech monarchii z Księgi Daniela i roli cesarza niemieckiego jako głowy ostatniej z nich, Melanchton, zafascynowany zarówno astrologia jak i kroniką Cariona, osadził teologicznie cały ciag tych proroctw w kontekście apokaliptyki nowotestamentowej i przewidywał nadchodzące rychło czasy ostateczne. W pierwszej księdze wyłożył podstawowy schemat proroctwa, traditio domus Eliae: pierwsze dwa millenia historii „puste” (inane), następne dwa „pod Prawem (Lex)” i ostatnie dwa jako „dni mesjańskie”, dies Messiae (Melanchton 1558, 14 i n.). Innym źródłem popularnym wśród szesnastowiecznych luteran było wydane po raz pierwszy w 1531 r. w Strasburgu obszerne dzieło mistyka i humanisty Sebastiana Francka Chronica, Zeitbuch und Geschichtbibel, historyczno-religijna encyklopedia dziejów, która ilustrowała historię upadku ludzkości od grzechu pierworodnego aż po czasy ostateczne, które Franck, jak wielu innych, uważał za sobie współczesne. Chronica miała też ogromne znaczenie dla rozwoju radykalnej reformacji - była na przykład jednym ze źródeł dla chrześcijańsko-apokaliptycznych komunistów, hutterytów. Pisane w ten sposób kronikochronologie, globalne historie świata, obejmujące zapowiedziane 6000 lat i uzupełniane starymi i nowymi proroctwami, nie były w tym okresie niczym wyjattkowym był to wręcz cały innowacyjny gatunek piśmiennictwa historyczno-religijnego, legitymizowanego przykładem samego Lutra (Barnes 1988, 108 i n.). Ze wspartych na autorytecie żydowskim i kronice Cariona obliczeń Lutra, pierwotnie na prywatny użytek, ale zaprezentowanych w końcu w druku jako obszerne kalendarium świata Supputatio annorum mundi (Obliczenia wieku świata, 1541, 1545), wynikało, że od początku świata upłynęło właśnie 5500 lat i rozpoczęła się druga połowa szóstego millenium. Zgodnie z Ps 90,4 tysiąc lat jest w oczach Boga jak jeden dzień, lecz Luter nieoczekiwanie wprowadził analogię z niepełnymi 
trzema dniami po Ostatniej Wieczerzy ${ }^{40}$, a zatem ostatnie millenium jako eschatologiczne przesilenie, zaczynające się od papieża Grzegorza VII i wzmożenia diabolicznej, kurialnej władzy papiestwa, miało być znacząco krótsze: historia zaczęła się zagęszczać, widoczne stały się znaki Antychrysta i zbliżał się nieuchronnie szabat ludzkich dziejów (Barr 1990; Maier 1981, 289 i n.). Luter, jak Melanchton, traktował proroctwo Eliasza bardzo poważnie jako rzeczywiście pochodzące od Eliasza biblijnego. Tertius status - czy trzecia era - a więc ostatnie dwa tysiące lat historii, musiał zacząć się w 40 r. n.e. wraz z soborem apostołów w Jerozolimie z 15. rozdziału Dziejów Apostolskich i zniesieniem starego Prawa na rzecz wolności Ewangelii („lex abrogatur \& libertas promulgatur a lege”). Melanchton uważał jednak, że szabat historii może nastapić znacznie wcześniej, niż wynika to z obliczeń, ze względu na rosnącą impietas, degradację moralną ludzkości (Schmidt-Biggemann 2004, 404). Tak czy inaczej, bliskość Eliasza zdawała się prawie wyczuwalna, ale z pewnością nie byłby to w tym przypadku „Eliasz nauk”, oksymoron w oczach Lutra (Gerrish 2004, 170 i n.). Między kościelnym Eliaszem Lutra, którego pojawienie się poprzedzaja wojenne trąby i trupy niewierzących, a Eliaszem Paracelsusa i jego uczniów, mających nad zieję na wielką reformację nauk, objawienie sekretów przyrody i możliwość przekształcania materii, zieje jednak przepaść (mimo że i sam Paracelsus spodziewał się, iż ostatecznie nie doczeka tego dwie trzecie ludzkości, zob. Moran 1994, 107).

Tym, co uderzające w lekturze luterańskich kronik, jest ich religijna innowacyjność, wypracowana systematyczność i konsekwencja: schemat czterech monarchii oraz trzech epok i szabatu służył w świecie luterańskim XVI wieku jako klucz do rozumienia całej historii, z reformacją włącznie, a więc jako „eschatologiczna koncepcja historii uniwersalnej” (Barnes 1988, 104). W drugiej połowie XVI wieku ich millenarystyczny charakter stał się jeszcze dobitniejszy: dobrym przykładem jest pisana w kontekście astrologicznych znaków lat 70. Chronologia czy też Jahrrechnung superintendenta z Legnicy Leonarda Krentzheima, wydana w Zgorzelcu w 1577 r., która zapowiadała „powszechną odnowę wszystkich rzeczy” (cyt. za: Barnes 1988, 111). Innym przykładem jest monumentalne Prognosticon Theologicum (1588) Adama Nachenmosera, odnoszące biblijne proroctwa do bieżących wydarzeń, i dokładnie na tym tle należy też osadzić późniejszy różokrzyżowo-apokaliptyczny tekst Confessio (1615). Wierzono, że pomimo przewidywanego pełnego biegu 6000 lat, okres mesjański i Paruzja może nastąpić z woli Boga znacznie wcześniej, w każdej chwili, a więc ten typ chronologicznego millenaryzmu nie pozwalał na jałowa demobilizację. Nie należy popełnić błędu uznawania tych wyobrażeń za marginalne, „fantastyczne” albo czysto ezoteryczne. Wręcz przeciwnie: niezależnie od kręgów paracelsjańskich były one szeroko znane

40 Schemat trzech epok z „proroctwa Eliasza” połączony z chronologią Męki Pańskiej zakłada, iż każde tysiąclecie (połowa epoki) to połowa dnia, a więc czasy Lutra odpowiadają bezpośrednio czasowi przed Zmartwychwstaniem. 
i wspierane przez wielu uczonych luteran, na przykład kopernikanistę Michaela Maestlina nauczyciela Keplera - którego publikacje na ten temat były popularne i cytowane nawet wśród szerszej publiczności (Barnes 1988, 113). Millenarystyczna apokaliptyka rozkwitała także w świecie reformowanym: być może najbardziej znaczacym, lecz antyezoterycznym millenarysta był wówczas teolog i biblista Johannes Piscator (1546-1625), który pośród ogromnej spuścizny piśmienniczej pozostawił również wpływowy komentarz do Apokalipsy św. Jana wydany w 1613 i wznowiony w 1621 r. (Piscator 1613). Najważniejszym prekursorem tych idei był oczywiście Joachim z Fiore, ale innym nieoczekiwa nym źródłem stała się też spisana pierwotnie po hebrajsku 4 Księga (Apokalipsa) Ezdrasza (Barnes 1988, 218 i n.), pochodząca z Palestyny z końca I w., w której anioł Uriel objawia wizjonerowi nadchodzące znaki czasów ostatecznych, nadejście mesjasza i sąd poprzedzający zmartwychwstanie oraz „raj radości” i która zawiera również wizję „Syna Człowieczego” wychodzącego z morza. 4 Księgę Ezdrasza w łacińskiej wersji dodawano niejednokrotnie do druków Wulgaty, ale ze względu na bardzo negatywną opinię Lutra była ona studiowana głównie przez millenarystycznie czy ezoterycznie nastawionych luteran i w kręgach radykalnych reformatorów takich jak Melchior Hoffmann (zob. najpełniejsze studium Alastaira Hamiltona, 1999).

Zarówno popularne proroctwa dotyczące „czwartej monarchii” krążące w okresie reformacji, Chronica Carionis Melanchtona, wspomniane Supputatio annorum mundi Lutra, Chronica Francka, Prognosticon Nachenmosera czy same pisma Joachima z pewnością miały tu kluczowe znaczenie, ale były one nieustannie reinterpretowane w oparciu o źródła ściśle ezoteryczne, zwłaszcza astrologiczne (w ramach tej samej tradycji co Carion) i kabalistyczne, wzbogacające biblijna historiozofię. W świecie arabskim istniała w szczególności wielka tradycja astrologii historycznej, która wpłynęła na całą astrologię zachodnią, w tym i żydowska. Jej kluczowe i najambitniejsze dzieła dotyczyły „obrotów świata” (arab. tahāwīl sinìl-'älam) - przede wszystkim księgi Masza'allaha (zwłaszcza słynny Kitāb tahāwìl sinìl- 'älam - Ksiega o obrotach lat świata znana w Europie od XII w. jako De revolutionibus annorum mundi ${ }^{41}$ ), Abu Ma'shara (Kitāb al-qirānāt - Ksiega koniunkecji znana jako De magnis coniunctionibus ${ }^{42}$ ), alSijzego czy Zahela. Na przykład różokrzyżowe „Rotae Mundi” („obroty/obiegi świata”) z Famy Fraternitatis ${ }^{43}$ ponad wszelką wątpliwość znajdują w nich swój pierwowzór i miały być

41 Czytelnicy w 2. poł. XVI w. mieli do niej dostęp przede wszystkim dzięki norymberskiej edycji Joachima Hellera z 1549 r. Na temat łacińskich przekładów Masha'allaha zob. Thorndike (1956).

42 Pierwsze wydanie drukiem wyszło w Augsburgu w 1489 r. pod tytułem De magnis coniunctionibus, annorum revolutionibus ac eorum profectionibus octo continens tractatus, przygotowane przez Johannesa Angelusa, drugie ukazało się w Wenecji w 1515 r. Była to jedna z najważniejszych ksiąg astrologicznych średniowiecza i renesansu, czytana i cytowana równie często co Tetrabiblos Ptolemeusza.

43 R 142.23-24 / FFG, 19 / FFU, 76 („,periodi seculorum”); także: R 147.14 / FFG, 27 / FFU, 82 („Rotae”); R 150.22 / FFG, 33 / FFU, 86 („Rotae Mundi”). W tym samym tekście „Rota” to również „horoskop chwili” (R 157.21). 
one astrologiczno-kosmologiczną wiedzą na temat wyznaczanego przez cykle planetarne biegu dziejów i następstwa historycznych epok. W tej samej, łacińskiej już tradycji szczególne miejsce zajmował Trithemius i jego traktat De septem secundeis ( $O$ siedmiu niższych prayczynach, Kolonia 1567), znany też z podtytułu jako Chronologia mystica z 1508 r., prezentujący historię świata, której 354-letnie okresy rządzone są przez siedem duchów (inteligencji) czy aniołów planetarnych. System Trithemiusa ma z pewnością swoje korzenie w astrologii arabskiej, w szczególności u Masha'allaha i Abu Ma'shara (Trithemius znał je prawie na pewno za pośrednictwem dzieł Piotra z Abano). Przepowiadał on rychłe powstanie „nowej sekty religii” i „obalenie starej religii”, zamykając swój traktat opisem końca panowania anioła Samaela w 1525 r. (roku apogeum wojen chłopskich w Niemczech) - te prognostyczne datowania wywierały na późniejszych czytelnikach duże wrażenie.

Oprócz astrologicznych dzieł arabskich, uznawanych wówczas za autorytatywne, pewien wpływ na kręgi ezoteryczne mogły też wywierać takie rzadkości jak Candelabri typici in Mosis tabernaculo interpretatio (1548) ekscentryka Guillaume’a Postela, będąca millenarystyczną interpretacją historii osnutą wokół symboliki siedmioramiennej menory i Pieśni nad Pieśniami. Chrześcijańscy kabaliści znali tę millenarystyczną symbolikę wiążąca dni stworzenia, epoki świata, anioły i ramiona menory, ale kwestią podstawową i poniekąd praktyczną było oczywiście określenie, czy czytać proroctwa literalnie, czy figuratywnie, kiedy rozpocznie się apokaliptyczny szabat, „zapalenie szóstego świecznika” oraz Paruzja, i czy o objawieniu tej nadchodzącej epoki, owych miranda sextae aetatis - jak o sabbatianizmie Postela - należy głośno mówić, czy też jest to wiedza dla wybranych, odpowiednio przygotowanych (kwestie te zastanawiały nawet Maestlina). Jedną rzeczą są bowiem luterańskie kroniki świata z proroctwem Eliasza i ostrożne prognostyczne uwagi Lutra, inną zaś szczegółowe astrologiczne kalendarium bliskich czasów ostatecznych i projekt przemian społecznych („Christianopolis”), które mają do nich przygotowywać. Jednym z wczesnych prekursorów takiej kabalistycznej apokaliptyki w świecie luterańskim był zwłaszcza Michael Stifel (bądź Stiefel, ok. 1486-1567), pierwszy luterański kaznodzieja w Austrii, były augustianin i późniejszy pierwszy profesor matematyki na uniwersytecie w Jenie, który na początku lat 20. stanął po stronie Lutra i oddał się studiom nad algebrą oraz kabalistyczno numerologicznym sensem Apokalipsy. W 1532 r. opublikował anonimowo swoja pracę Rechen Büchlein vom End Christ (Ksiażeczka obliczeñ na temat Antychrysta), w której na drodze kabalistycznych obliczeń i spekulacji utożsamił papieża Leona X z apokaliptyczną Bestią i przewidywał koniec świata na 19 października 1533 r. (Reich 1996, 159-172; Koetsier, Reich 2005, 291-310). W tym przypadku, jak i wielokrotnie później, synteza matematyki i apokalipsy okazała się, zgodnie zresztą ze starożytną tradycją, bardzo polityczna.

Jednocześnie, w tym samym czasie, millenarystyczne dyskursy przechodza zaskakująca mutację, która zasadniczo odbiega od ortodoksji luterańskiej i reformowanej: 
fascynacja przyroda i „nowymi naukami” zaczyna w wyobraźni historycznej sprzęgać się z obrazami nadchodzącej rewolucyjnej epoki i wezwaniami do politycznego aktywizmu. Dobrej ilustracji millenaryzmu w sojuszu ze spekulatywną (kosmologiczna) apokaliptyką, nasilającego się w pietystycznych kręgach paracelsjańskich pod koniec XVI wieku, dostarczają - obok niewydanej nigdy, ale czytanej w rękopisie Naometrii Studiona (ok. 1543-ok. 1606) ${ }^{44}$, badającego za Trithemiusem kolejne epoki, Kościoły i zapalane apokalip tyczne „świeczniki” - dwa szczególne dokumenty, które nie ukazały się wówczas w druku i krążyły w postaci odpisów (oba pominął w swoim wcześniejszym studium Robin Barnes). Pierwszym jest napisana w 1597 r. i następnie rozszerzana praca Juliusa Sperbera Von dreyerley Seculis oder Hauptżeiten, Tröstlicher Prophecey und W eissagung (Pocieszajace proroctwo iprzepowiednia o trzech wiekach albo epokach), wydrukowana w końcu w Amsterdamie przez Benedicta Bahnsena w 1660 r. Drugim jest niewydana nigdy, pisana krótko potem - na przełomie stuleci - praca Paula Lincka Rechter Bericht von den Dreyen Seculis und Judiciis Divinis post Dilwium (Prawdziwy wyktad o trzech wiekach $i$ Bożych wyrokach po Potopie; zob. Gilly 1995, 20), zachowana obecnie w co najmniej trzech kopiach. Innym jest zaś wydrukowany pośpiesznie w Lich w 1604 r. traktat paracelsjańskiego schwenckfeldysty, wykształconego w Tybindze lekarza i as trologa z Alzacji, Heliasaeusa Roeslina: Speculum et Harmonia Mundi: Das ist Welt Spiegell... (Zwierciadto i harmonia świata...; zob. Gilly 1995, 12), krążący jednak w rękopisie przez co najmniej dwie dekady (rozprowadzał je wśród zainteresowanych zapewne sam autor). Nie byli oni jednak jedyni: Raphael Eglin wydawał kolejne edycje swojego wspomnianego już alchemicznego dzieła na temat Eliasza, zaś wymieniony już „Teofil Schweighardt” (Mögling) opublikował w 1617 r. Pandora sextae aetatis (Pandore szóstej epoki).

Paracelsysta i kabalista Sperber rozwija apokaliptyczną narrację według triadycznego schematu Joachima z Fiore i proroctwa Eliasza (Sperber 1660, 145), ale modyfikuje i uzupełnia je o mnóstwo nowych elementów. Pierwsza epoka „pod Prawem” to epoka Boga Ojca, Starego Testamentu i judaizmu, której prorokiem jest Mojżesz, „Electus Dę” (Wybraniec Boga) i która wykształciła intellectus moralis; druga to wciąż trwająca epoka Chrystusa, „Filius Dei” (Syna Bożego) i religii Nowego Testamentu („ewangelii łaski Bożej”, scil. dotychczasowego chrześcijaństwa) z jej intellectus allegoricus, zaś trzecia, nowa epoka mesjańska Ducha Świętego - Królestwa Bożego, „nowej ziemi i nowego nieba” i „,nowej księgi” z Ap 5,1, ma swojego zapowiadanego proroka - Eliasza, „Angelus De乞” (Anioła

\footnotetext{
${ }^{44}$ Studion - wirtemberski filolog, poeta, genealog i chrześcijański kabalista, pełniący funkcję luterańskiego pastora w Marbach niedaleko Stuttgartu - studiował wcześniej w Tybindze (uzyskał stopień w 1565 r.) i utrzymywał kontakty z tamtejszymi środowiskami, w szczególności z Tobiasem Hessem (obaj byli w Tybindze studentami wybitnego filologa i historyka Martina Crusiusa); zob. np. Gilly (1995, 21), Dickson $(1998,33)$ i Åkerman (1998, 97 i n.). W Naometrii „generalna reformacja świata”, nadejście Civitas Solis po pokonaniu papieża-Antychrysta i katolicyzmu, miała dopełnić się w roku 1620. Sama koncepcja dzieła - „naometria” to „mierzenie świątyni” - jest chyba odległym, historiozoficznym wariantem starożytnej żydowskiej apokaliptyki teozoficznej Szíur koma, „miary ciała (Boga)”. Dla Studiona „świątynia zewnętrzna” to przyroda.
} 
Bożego), który powróci, by rozpocząć odnowę wszystkich rzeczy zgodnie z proroctwem z Ml 3,23-24 (Sperber 1660, 19). Cała trzecia, najobszerniejsza część dzieła poświęcona jest tej odnowie i przypomina pod tym względem manifesty różokrzyżowe: wraz z epoką Eliasza nadejdzie nowa religia i nowa teologia „Wiecznej Ewangelii”, Ewiges Evangelium z Ap 14,6 (Sperber 1660, 161 i n.), „teologia Ducha Świętego” (Sperber 1660, 42), a także nowa filozofia, medycyna i nowa nauka (jako ich pionierów Sperber wymienia m.in. Lutra, Paracelsusa, Agryppę von Nettesheima i - co intrygujące - Postela, „paryskiego profesora i bardzo uczonego męża”). Sperber szczegółowo wylicza ostatnie antyarystotelesowskie postępy w wiedzy i osiagnnięcia naukowe jako znaki, iż ludzkość zbliża się do „złotej epoki” i nowa, radykalna filozofia położy podwaliny pod ponowny rozkwit sztuk podupadłych przez stulecia. W tym opisie nadchodzącej epoki „nowych nauk” idzie oczywiście śladem wcześniejszych autorów paracelsjańskich, takich jak Samuel „Siderocratus” [Eisenmengern] i przygotowanej przez niego monumentalnej Cyclopedia Paracelsica Christiana wydanej w Strassburgu w 1585 r., która w całości jest właściwie radykalnym paracelsjańskim manifestem. Sperber, podobnie jak Haslmayr czy Linck głęboko oddany paracelsjańskiej religii przyszłości, „,Theophrastia Sancta” (Gilly 1994), rozumiał zapowiedź nastania „Wiecznej Ewangelii” całkiem dosłownie jako następne Nowe Przymierze ludzkości z Bogiem, gdy znikną oddzielne Kościoły i istnieć będzie tylko jedna Ecclesia-Zgromadzenie wybranych: z nowym sakramentem (namaszczeniem ogniem-duchem, takim, jakie otrzymał Jezus w Jordanie) i zupełnie nowym rozumieniem tajemnic Pisma Świętego za pomoca intellectus mysticus (gnozy). Moment spirytualistyczny paracelsyzmu jest tu w pełnym rozkwicie, ale działa w całkowitej symbiozie z politycznym aktywizmem, który nie toleruje „starych nauk”. Przepowiednie te - zgodnie z tytułem - musiały być dla wielu radykalnych uczonych pietystów oczekujących Eliasza bardzo pocieszające i mobilizujące, ale były przede wszystkim obwieszczeniem, że nieodwracalnie zmienia się kształt świata i po naukowo-mistycznej rewolucji nic nie będzie wyglądać tak jak wcześniej. Brzmiały one równie atrakcyjnie, jeśli nie bardziej, sześćdziesiąt lat po ich sformułowaniu, gdy amsterdamski druk Traktatu towarzyszył narodzinom Towarzystwa Królewskiego w Londynie.

Także Linck, równie radykalny i chiliastyczny paracelsysta jak Sperber, opierał się na joachimickim triadycznym schemacie dziejów, kabalistycznym proroctwie o mesjańskim powrocie Eliasza oraz Henocha (które w rozwiniętej postaci odnajdujemy w średniowieczu na przykład u Abrahama Abulafii), ale też wizji siedmiu anielskich epok Trithemiusa, pisząc swój traktat w gorączkowej atmosferze oczekiwania na wyjątkowe wydarzenia roku 1602. Linck był też dobrze zorientowany w dziełach Postela i - podobnie jak Sperber - wymienia go, obok m.in. Paracelsusa, jako proroka nowej, nadchodzącej epoki. Rękopis ten jest też o tyle interesujacy, że oparty jest na teologicznych manuskryptach samego Paracelsusa, do których Linck dotarł (Gilly 1994, 449), ale które nie mogły z powodu cenzury znaleźć się 
w monumentalnej edycji pism Paracelsusa (1589-1590) przygotowanych wcześniej przez Lincka razem z katolikiem Huserem w Bazylei (z imprimatur i finansowaniem ze strony arcybiskupa Kolonii!). Susanna Åkerman (1998, 115) zwróciła poza tym uwagę, że wzmiankuje on również za Trithemiusem „Bractwo Dni Ostatnich”, co także jest zbieżne z wyobrażeniem Sperbera na temat apokaliptycznej ecclesiae oraz z legendą o „Bractwie RóżoKrzyża” z Famy i Confessio. Eliasz Artysta, którego nadejście rozpocznie trzecią epokę i „druga Restaurację” (po ewangelicznej), miał być według Lincka zarówno „Reformatorem Teologii”, jak i mesjaszem wszystkich nauk.

Podobnie jak Sperber i Linck widział to Oswald Croll, który w przedmowie do swojej słynnej Basilica Chymica (1. wyd.: Frankfurt 1609) wiąże nadchodząca epokę Ducha Świętego, „das dritte seculum des Heyligen Geistes”, z ujawnieniem niedostępnych wcześniej sekretów natury za sprawą wytężonej pracy eksperymentatorów-paracelsystów „,z pomocą Oratorium i Laboratorium", zwieńczonej nadejściem Eliasza Artysty (Croll 1623, 4 i n.). Typowe dla alchemoparacelsystów sprzężenie-hybryda „oratorium” i „laboratorium”, którego najsłynniejsze wizualne przedstawienia znajdujemy u Khunratha (zob. np. Forshaw 2010) i w przywołanym wcześniej Speculum... Möglinga, działa tu płynnie na polu eschatologii, generując chiliastyczny optymizm. Przyszła epoka powszechnego objawienia należy do eksperymentatorów i lekarzy.

Z kolei paracelsjański schwenckfeldysta Roeslin (Åkerman 1998, 104 i n.; Gilly 1994, 440 i n.) zainteresowany był chronologiami świata i ich astrologicznym rytmem, ,obiegami” (wzór takiej chronologii miał zarówno w Chronicon Carionis, jak i u Trithemiusa). Sam będąc aktywnym astrologiem, zajmował się intensywnie tym, co się dzieje na niebie: począwszy od „nowej gwiazdy” Tychona z 1572 r., aż po kolejną „nowa gwiazdę” (która sam zauważył) i wielką potrójną koniunkcję w Strzelcu z 1604 ${ }^{45}$. Interesował się również kabałą i właśnie na tej drodze stał się wielkim zwolennikiem Postela, być może najbardziej znaczącym w ówczesnych Niemczech - udał się nawet w 1581 r. do Paryża, by go spotkać, wówczas jednak Postel już nie żył. Speculum et Harmonia Mundi... Roeslina, którego manuskrypt ukończony został około 1579 r., zostało wydane bez jego wiedzy i zgody, w okrojonej wersji, zapewne w wyniku nagłego zapotrzebowania na taki komentarz w związku z sensacyjnymi astrologicznymi fenomenami i pragnieniem zrozumienia ich politycznego znaczenia. Wywołało ono (niewroga) polemikę ze strony Keplera - od dawna przyjaciela Roeslina, podobnie jak Maestlin ${ }^{46}$ - która trwała przez następne lata i przyciągała uwagę kręgów

\footnotetext{
45 Więcej na temat apokaliptyki Roeslina: Granada (2006) i przede wszystkim, w związku z manuskryptem De potestatibus orbis Christiani... z ok. 1580, przypisywanym Roeslinowi: Granada (2013).

46 Gorąco dyskutowany i prawdopodobnie pierwszy w Europie komentarz Roeslina do ukazania się „,nowej gwiazdy" w 1604 r., Judicium..., został zreszta wydrukowany jako apendyks w drugim wydaniu znanej pracy Keplera Gründlicher Bericht und Bedencken von einem ungewöbnlichen Nenen Stern (Amberg 1605), jednak bez wiedzy obydwu.
} 
proróżokrzyżowych. Dzieło Roeslina nie jest jednak czysto astrologiczne, lecz przede wszystkim apokaliptyczne, bazujące na tych samych ezoterycznych źródłach (z 4 Księga Ezdrasza włącznie) i spekulatywnych przesłankach co prace Sperbera i Lincka - to właśnie wywoływało niechęć Keplera, zdecydowanie preferującego „czysta” matematyczną astrologię koniunkcjonistyczną w arabskim stylu i unikającego niejasnych eschatologicznych proroctw. Dla Roeslina, podobnie jak dla kręgów różokrzyżowych czy Campanelli, znaki astrologiczne z lat 1603-1604 były jednak zapowiedziami wielkich, gwałtownych przemian, renovatio świata i „nowej reformacji” pod znakiem ognia (ze względu na trygon znaków ognistych, w którym miała miejsce koniunkcja planet), a nawet Paruzji. Spodziewał się „powszechnej rewolucji” (allgemein catastrophe) w roku 1604, czegoś, „co przekracza myśli wszystkich ludzi” i co rozpocznie okres „największej i powszechnej Przemiany” (die gröste und Universal Mutation) w latach 1604-1642 (Granada 2013, 237 i 257). Przewidywal poprzedzające ja wielkie wstrząsy w świecie chrześcijańskim, łącząc „nową gwiazdę” i koniunkcję z kometą, która pojawiła się w 1580 r. Te prognozy mają jednak bardzo specyficzny charakter, odróżniący je od katolickiej apokaliptyki eschatologicznej i zarazem sytuujący je w politycznym sojuszu z Linckiem, Sperberem, Eglinem czy Haslmayrem: dla Roeslina, paracelsjańskiego ucznia Eisenmengerna, nadchodząca epoka Eliasza to e poka nowej na uki, w szczególności nowej kosmologii i medycyny, a studium ukrytego porządku historii, speculum mundi, wiąże się bezpośrednio z odkrywaniem tajemnic całego wszechświata i zarazem biblijnej historii stworzenia, speculum naturae, jak w jego De opere Dei creationis (1597). Rytmy kosmosu i tajemnice przyrody wraz z labiryntem ludzkiej historii stały się więc elementami jednej zagadki do rozwiązania: mesjańskie obietnice Eliasza wybiegają tu daleko poza rozjaśnienie trudnych fragmentów Pisma i na pewno nie maja zachęcać wystraszonych wiernych do zapełniania świątyń, takich czy innych. „Powszechna Rewolucja” ma zmieść ze sceny historii starą naukę, filozofię i teologię.

Postać Eliasza zachowała swoja obecność jeszcze długo po pierwszej fali piśmiennictwa różokrzyżowego. Tacy teozoficzni alchemicy - teoalchemicy (J. Telle) - jak Johann Hartprecht, ukrywający się pod pseudonimami „Filius Sendivogii” i „Hautnorthon”, wciąż czekali na jego nadejście i wielką reformę nauk, które rozpoczną apokalupsis - pozwola wydobyć ukryte „światło natury” (Trepp 1999, 486). Wzmiankuje jego przyjście, wciąż z nadzieja, na przykład wybitny holenderski anatom i chemik o paracelsjańskich sympatiach Theodor Kerckring (1638-1693, od 1678 r. członek Towarzystwa Królewskiego) w swoim komentarzu do Basiliusa Valentinusa: „Czy nie są bliskie w końcu owe czasy, kiedy przyjść ma Eliasz Artysta, odkrywca wyższych tajemnic (der grössern Geheimnüsse Entdecker)? Którego przyjście tak jasno i wyraźnie zapowiadał w różnych miejscach Paracelsus?”, po czym przytacza odpowiednie cytaty z Paracelsusa (Kerckring 1724, 183). Johann Rudolf Glauber w połowie XVII wieku pisał: 
Wielu Filozofów, poza Paracelsusem, przepowiadało nadejście Eliasza Artysty (...), który, jak powiedział, gdy przyjdzie, będzie nauczał sposobu, jakim można dokonać Transmutacji Metali. Tak ludzie (...) spodziewają się przyjścia pewnego Człowieka zesłanego przez Boga, który - jak wierza - odkryje im w późniejszych epokach świata tajemne Sztuki i odsłoni Sekrety Natury ${ }^{47}$.

(Dla Glaubera Eliasz/salia nie był już jednak człowiekiem, lecz - poprzez anagram Elias Artista = Et Artis Salia, „i Sole Sztuki” - kryptonimem chemicznej części Kamienia Filozoficznego, solą umożliwiająca przemiany metali.) Niedługo potem znany holenderski lekarz i alchemik, Johannes Fredericus Helvetius (1625-1709) donosił w wydanej w Amsterdamie w 1667 r. broszurze Vitulus aureus (Złote ciele) swojego autorstwa, iż spotkał Eliasza Artystę osobiście: mistrz miał odwiedzić go w Boże Narodzenie 1666 r. w jego domu w Hadze, a następnie ponownie trzy tygodnie później, przekazując mu niewielka ilość Kamienia Filozoficznego (Read 1958, 1118). Helwecjuszowi był skłonny wierzyć Spinoza (znajomy Kerckringa jeszcze z amsterdamskiej szkoły van den Endena), który wpierw konsultował to ze złotnikiem, a potem sam odwiedził go w Hadze i oglądał kamień, o czym otwarcie napisał w jednym ze swych listów do Jariga Jellesa z 25 marca 1667 roku, odnosząc się do całej afery. Tajemniczy nieznajomy, wędrowny alchemiczny prorok, odwiedził Helwecjusza dokładnie tak samo, jak w końcu poprzedzającego stulecia zrobił to w przypadku młodego Jakoba Boehmego w Zgorzelcu: trudno oprzeć się wrażeniu, że za tymi opowieściami stoi jedna i ta sama tradycja paracelsjańska. Postać wędrownego Eliasza była wówczas ciagle atrakcyjna, tak że - na długo po różokrzyżowym furor w Niemczech wciąż pojawiali się jeszcze w Europie „artyści”, dając nawet początek swego rodzaju gatunkowi: siedemnastowiecznej „opowieści o transmutacji”, jak to ujął William R. Newman $(1994,4)$.

Po wyniszczającej wojnie trzydziestoletniej, gdy poreformacyjny millenaryzm i polityczny entuzjazm wygasły, tradycja ta wytraciła jednak wigor i nabrała raczej mdłego, anegdotycznego wyrazu, co pokazuje, jak silnie mit Artysty sprzężony był pierwotnie z gorąca chiliastyczna apokaliptyka protestancka, podzielając w części jej los. Obecność tej hybrydy Eliasza nauk i nadzieja na nowa ,,reformację świata” przygasły, a fizyka i astronomia zaczęły się rozwijać, nie oglądając się na swojego mesjasza i na żadnego innego. W tym samym czasie przyroda zaczęła na dobre stawać się dla teologów nie tyle fascynującym hieroglifem, co raczej niedostępną enigmą, pozostawioną do eksploracji przyrodnikom. Zupełnie nieskutecznie próbował to zahamować filozoficzny romantyzm, dla którego grunt przygotował szwabski nurt teozoficznego, postparacelsjańskiego pietyzmu, na równi

${ }^{47}$ Johann R. Glauber, Works (transl. Christopher Packe, London 1689, cz. I, s. 222), cyt za: Read (1958, 1119). Zob. Breger (1984, 63). 
zainteresowanego i Bogiem czy aniołami, i elektrycznością, mineralogia czy chemia (w ostatniej fazie Friedrich Christoph Oetinger, Johann Ludwig Fricker, Philipp Matthäus Hahn i inni). Ale przyroda stała się dla religii obca, oddzieloną domeną być może i dlatego, że załamaniu uległa także antyscholastyczna mistyka przyrody, uparcie towarzysząca jak niechciany sobowtór głównemu nurtowi protestanckiego millenaryzmu, a dominację zdobył ekstremalnie dualistyczny model kartezjański, projektujący przyrodę jako obce duchowi, mechaniczne „Inne”, co jest modelowym przykładem działania Latourowskiej puryfikacji, umożliwiającej sprawny podział pracy między teologię i mechanikę. Mistyka ta jednak w żadnym razie nie była odosobnionym fenomenem, ponieważ pojawiła się i trwała na gruncie o wiele szerszej formacji intelektualnej, którą tu konsekwentnie nazywam kosmologiczną albo przyrodniczą apokaliptyka. Powtarza się tu scenariusz z późnego antyku: apokaliptyka jest pierwsza, mistyka przychodzi później, będąc jej przekształconą, uwewnętrznioną forma. Nawet po wygasaniu afektów millenarystycznych z ich Eliaszem właśnie ta wertykalna apokaliptyka w XVII wieku nadal stanowiła niezwykle witalną, nośna część wczesnej nowoczesności jako religijny lub parareligijny rezerwuar poznawczych motywacji nauki (philosophia naturalis).

Podsumowując: ideologiczne batalie wczesnej nowoczesności ogniskowały się wokół kwestii „,sekretów materii”, które okazały się z wielu powodów zagrażające i rzeczywiście przyczyniły się do końcowego rozmontowania scholastyki jako metafizycznego schematu i zarazem pola władzy. Po drugie, nieprawdziwa jest konserwatywna teza, że apokaliptyka przyrodnicza wprowadziła jedynie nowe, „nieprawomocne” tematy czy aspekty do chrześcijańskiej eschatologii - wręcz odwrotnie, spowodowała ona jej rekonfiguracje czy mutacje, stymulujac afekt religijny w nowych kierunkach i neutralizując znaczenie eschatologii. Nie sposób zrozumieć tej mutacji, ignorując nowe typy praktyk medycznych i chemicznych, które wytwarzały swoje hybrydowe ontologie w kontekście głębokich konfliktów religijnych po reformacji. Po trzecie, tradycyjne zaprzeczanie, zwłaszcza przez teologów, by można w ogóle mówić o „mistyce przyrody”, jest elementem tych historycznych batalii i wiąże się z apologetycznymi próbami powstrzymania panteizmu jako specyficznej formy tych wczesnonowoczesnych hybrydowych ontologii. Po czwarte, ujmując rzecz po latourowsku, translacyjne pole tej mistyki i apokaliptycznej „religii laboratorium" było w drugiej połowie XVI i przez cały XVII wiek kluczowe dla intensyfikowania przebiegu przeciwstawnej pracy puryfikacji, choć dawna historiografia miała kłopot, by to zrozumieć. Ale historyka nauki nie powinien ani przez chwilę dziwić Kepler, który w swoim kopernikańskim Mysterium Cosmographicum (Tybinga 1596) usiłował odtworzyć matematyczną architekturę kosmosu, „mundi fabrica”, jako odzwierciedlenie Trójcy Świętej „idea Creationis”, i traktował całą swoją późniejszą pracę jako jego rozwinięcie (Martens 2000, 39 i n.). Ani też katolik Kartezjusz, odwiedzający w Ulm w przełomowym dla niego 1619 
roku wybitnego matematyka, różokrzyżowca-apokaliptyka Johanna Faulhabera i podejmujący młodzieńcza próbę reformy matematyki (Shea 1988; Åkerman 1998, 221 i n.; Sasaki 2003, 149 i n.); ani Francis Bacon, od drugiej dekady XVII wieku uważający rewolucję naukową za szczytowy okres dziejów, zgodne z biblijnymi proroctwami przywrócenie ludzkości rajskiego stanu władzy nad naturą przez odsłonięcie jej sekretów. Ani tym bardziej gardzący katolicyzmem jako pogańską idolatrią Newton, obsesyjnie poświęcający miesiącami więcej czasu nocnym eksperymentom alchemicznym i studiowaniu każdego słowa Apokalipsy św. Jana niż matematyce i fizyce.

Ilustracje pochodzą ze zbiorów własnych autora. 


\section{Wykaz literatury}

PSW Paracelsus (Theophrast von Hohenheim). 1922-1933. Sämtliche Werke. Medizinische, naturwissenschaftliche und philosophische Schriften (I. Abteilung, t. 1-14). Hg. von Karl Sudhoff. München - Berlin: R. Oldenbourg.

Åkerman, Susanna. 1998. Rose Cross Over the Baltic: The Spread of Rosicrucianism in Northern Europe. Leiden: Brill.

[Andreae, Johann Valentin]. 2006. „Fama Fraternitatis, czyli odkrycie Bractwa przesławnego Zakonu R.C. Confessio Fraternitatis". Tłum. Jerzy Prokopiuk. Ars Regia IX/15-16: 50-73. [FFP]

Andreae, Johann Valentin. 2010. Rosenkreuzerschriften (Johann V. Andreae, Gesammelte Schriften, hg. von Wilhelm Schmidt-Biggemann, t. 3). Bearbeitet, übersetzt, kommentiert und eingeleitet von Roland Edighoffer. Stuttgart - Bad Cannstatt: frommann-holzboog. [R]

Barnes, Robin B. 1988. Prophecy and Gnosis: Apocalypticism in the Wake of the Lutheran Reformation. Stanford: Stanford University Press.

Barr, James. 1990. „Luther and Biblical Chronology”. Bulletin of the John Rylands University Library of Manchester 72: 51-67.

Bauer, Barbara. 1999. „Die Chronica Carionis von 1532. Melanchtons und Peucers Bearbeitung und ihre Wirkungsgeschichte". W Himmelszeichen und Erdenwege. Johannes Carion (1499-1537) und Sebastian Hornmold (1500-1581) in ibrer Zeit, red. Elke Osterloh. Ubstadt-Weiher: Verlag Regionalkultur.

Bennett, Jane. 1997. „The Enchanted World of Modernity: Paracelsus, Kant, and Deleuze”. Cultural Values 1: 1-28.

Besold, Christophorus. 1616. Axiomata Philosophico-Theologica: vitam vere philosophicam utcunque adumbrantia. Strasburg: Lazarus Zetzner.

Bloch, Ernst. 1985a. Das Materialismusproblem, seine Geschichte und Substan₹. Frankfurt am Main: Suhrkamp.

Bloch, Ernst. 1985b. Experimentum Mundi. Frage, Kategorien des Herausbringens, Praxis. Frankfurt am Main: Suhrkamp.

Blumenberg, Hans. 1974. Säkularisierung und Selbstbehauptung. Frankfurt am Main: Suhrkamp.

Brecht, Martin. 1967. ,Johann Valentin Andreaes Versuch einer Erneuerung der Württembergischen Kirche im 17. Jahrhundert”. W Martin Brecht, Kirchenordnung und Kirchenzucht in Württemberg von 16. bis zum 18. Jabrhundert. Stuttgart: Calwer Verlag.

Brecht, Martin. 1977. „Johann Valentin Andreae. Weg und Programm eines Reformers zwischen Reformation und Moderne”. W Theologen und Theologie an der Universität Tübingen. Beiträge zur Geschichte der Evangelisch-Theologischen Fakultät, red. Martin Brecht. Tübingen: Mohr.

Brecht, Martin. 1993. „Das Aufkommen der neuen Frömmigkeitsbewegung in Deutschland”. W Geschichte des Pietismus. Bd. 1: Das 17. und frühe 18. Jahrhundert, red. M. Brecht. Göttingen: Vandenhoeck \& Ruprecht.

Breger, Herbert. 1984. „Elias Artista - A Precursor of the Messiah in Natural Science”. W Nineteen Eighty-Four: Science between Utopia and Dystopia, red. Everett Mendelsohn i Helga Nowotny. Dordrecht - Boston - Lancaster: D. Reidel. 
Brown, Raymond E. 1968. The Semitic Background of the Term 'Mystery' in the New Testament. Philadelphia: Fortress.

Bubenheimer, Ulrich. 1995. „Orthodoxie - Heterodoxie - Kryptoheterodoxie in der nachreformatorischen Zeit am Beispiel des Buchmarkts in Wittenberg, Halle und Tübingen". W 700 Jabre Wittenberg. Stadt- Universität- Reformation, red. Stefan Oehmig. Weimar: Verlag Hermann Böhlaus.

Bubenheimer, Ulrich. 1999. „Rezeption und Produktion nonkonformer Literatur in einem protestantischen Dissidentenkreis des 17. Jahrhunderts”. W Religiöse Devianz in christlich geprägten Gesellschaften. Vom hohen Mittelalter bis zur Frühaufklärung, red. Dieter Fauth i Daniela Müller. Würzburg: Religion \& Kultur Verlag.

Burrows, Millar. 1952. „The Messiahs of Aaron and Israel (DSD IX,11).” Anglican Theological Review 34: 202-206.

Collins, John J., red. 1979. Apocalypse: The Morphology of the Genre (Semeia 14). Missoula/MT: Scholars Press.

Copenhaver, Brian P. 1990. „Natural Magic, Hermetism, and Occultism in Early Modern Science". W Reappraisals of the Scientific Revolution, red. David C. Lindberg i Robert S. Westman. Cambridge: Cambridge University Press.

Croll, Oswald. 1623. Osvaldii Crollii Vett. Basilica Chymica oder Alchymistisch Königlich Kleynod. Frankfurt am Main: Gottfried Tampach.

Debus, Allen G. 1977. The Chemical Philosophy: Paracelsian Science and Medicine in the Sixteenth and Seventeenth Centuries, 2 t. New York: Science History Publications.

Descartes, René. 1996. Listy do Regiusa. Uwagi o pewnym pisemku. Tłum. Jerzy Kopania. Warszawa: Wyd. Naukowe PWN.

Dickson, Donald R. 1998. The Tessera of Antilia: Utopian Brotherhoods and Secret Societies in the Early Seventeenth Century. Leiden-Boston-Köln: Brill.

Dobbs, Betty Jo T. 1991. The Janus Faces of Genius: The Role of Alchemy in Newton's Thought. Cambridge: Cambridge University Press.

Dorn, Gerhard. 1659. De transmutatione metallorum. W Theatrum Chemicum, praecipuos selectorum auctorum tractatus de chemiae et lapidis philosophici antiquitate, veritate, iure, praestantia, \& operationibus continens, (...) volumen primum. Strassburg: Lazarus Zetzner.

Eamon, William. 1984. „Arcana Disclosed: The Advent of Printing, The Books of Secrets Tradition and the Development of Experimental Science in the Sixteenth Century". History of Science 22: 111-150.

Eamon, William. 1994. Science and the Secrets of Nature: Books of Secrets in Medieval and Early Modern Culture. Princeton, NJ: Princeton University Press.

Faivre, Antoine. 2002. „Elie Artiste, ou le Messie des Philosophes de la Nature (première partie)". Aries 2: 119-152.

Faivre, Antoine. 2003. „Elie Artiste, ou le Messie des Philosophes de la Nature (seconde partie)". Aries 3: 25-54.

Fama Fraternitatis Oder Entdeckung der Brüderschafft des löblichen Ordens dess Rosenkreutzes. Beneben der Confession Oder Bekantnuss derselben Fraternitet, an alle Gelehrte und Häupter in Europa geschrieben. 1615. Danzig (Gdańsk): Andreas Hünefeld. [FFG]

Ferguson, John. 1906. Bibliotheca Chemica: A Catalogue of the Alchemical, Chemical and Pharmaceutical Books in the Collection of the Late James Young of Kelly and Durris, vol. 1. Glasgow: J. Maclehose and Sons. 
Forshaw, Peter J. 2010. „Oratorium - Auditorium - Laboratorium: Early Modern Improvisations on Cabala, Music, and Alchemy". Aries 10(2): 169-195.

Foucault, Michel. 2000. Stowa i rzeczy. Archeologia nank humanistycznych, t. I. Tłum. Tadeusz Komendant. Gdańsk: słowo/obraz terytoria.

Fuller, Steve. 2009. Nauka vs religia? Inteligentny projekt a zagadnienia ewolucji. Tłum. Tomasz Bieroń. Poznań: Zysk i S-ka.

Gerrish, Brian A. 2004. The Old Protestantism and the New: Essays on the Reformation Heritage. London-New York: T. \& T. Clark.

Gilly, Carlos. 1986. Johann V alentin Andreae 1586-1986. Die Manifeste der Rosenkreuzerbruderschaft. Katalog einer Ausstellung in der Bibliotheca Philosophica Hermetica. Amsterdam: BPH.

Gilly, Carlos. 1994. „»Theophrastia Sancta«. Der Paracelsismus als Religion im Streit mit den offiziellen Kirchen”. W Analecta Paracelsica. Studien zum Nachleben Theophrastvon Hohenheims im deutschen Kulturgebiet derfrühen Neuzeit, red. Joachim Telle. Stuttgart: Franz Steiner Verlag.

Gilly, Carlos, red. 1995. Cimelia Rhodostaurotica. Die Rosenkeveuzer im Spiegel der zwischen 1610 und 1660 entstandenen Handschriften und Drucke. Ausstellung der Bibliotheca Philosophica Hermetica Amsterdam und der Herzog August Bibliothek. Wolfenbüttel. Amsterdam: In de Pelikaan.

Gilly, Carlos. 1997. „Johann Arndt und die «dritte Reformation» im Zeichen des Paracelsus”. Nova Acta Paracelsica. Neue Folge 11: 60-77.

Goldammer, Kurt. 1948. „Paracelsische Eschatologie. Zum Verständnis der Anthropologie und Kosmologie Hohenheims". Nova Acta Paracelsica 5: 45-85.

Goldammer, Kurt. 1953. Paracelsus. Natur und Offenbarung. Hannover: Theodor Oppermann Verlag.

Goldammer, Kurt. 1964. Paracelsus. Humanisten und Humanismus. Ein Beitrag zur kultur- und geistesgeschichtlichen Stellung Hohenheims (Salzburger Beiträge zur Paracelsusforschung, t. 4). Wien: Verband der Wissenchaftlichen Gesellschaften Österreichs.

Goldammer, Kurt. 1986. Paracelsus in neuen Horizonten. Gesammelte Aufsätže (Salz̧burger Beiträge zur Paracelsusforschung, t. 24). Wien: Verband der Wissenchaftlichen Gesellschaften Österreichs.

Goldish, Matt. 2004. The Sabbatean Prophets. Cambridge: Harvard University Press.

Golitzin, Alexander (2001). ,„Earthly Angels and Heavenly Men«: The Old Testament Pseudoepigrapha, Niketas Stethatos, and the Tradition of «Interiorized Apocalyptic» in Eastern Christian Ascetical and Mystical Literature”. Dumbarton Oaks Papers 55: 125153.

Granada, Miguel A. 2006. „Helisaeus Rößlin on the Eve of the Appearance of the Nova of 1604. His Eschatological Expectations and His Intellectual Career as Recorded in the »Ratio Studiorum et Operum Memorum« (1603-1604)”. Sudhoffs Archiv 90: 75-96.

Granada, Miguel A. 2013. „Helisaeus Roeslin’s Chronological Conception and a New Manuscript Source". Early Science and Medicine 18: 231-265.

Greyerz, Kaspar von. 1999. „Alchemie, Hermetismus und Magie. Zur Frage der Kontinuitäten in der wissenschaftlichen Revolution". W Im Zeichen der Krise. Religiosität im Europa des 17. Jahrbunderts, red. Hartmut Lehmann i Anne-Charlott Trepp. Göttingen: Vandenhoeck \& Ruprecht.

Gruenwald, Ithamar. 1973. „Knowledge and Vision: Towards a Clarification of Two

'Gnostic' Concepts in Light of Their Alleged Origin'. Israel Oriental S tudies 3: 63-107.

Gruenwald, Ithamar. 1980. Apocalyptic and Merkavah Mysticism. Leiden: Brill. 
Hacking, Ian. 2002. Historical Ontology. Cambridge - London: Harvard University Press. Hamilton, Alastair. 1999. The Apocryphal Apocalypse: The Reception of the Second Book of Esdras (4 Ezra) from the Renaissance to the Enlightenment. Oxford: Oxford University Press.

Hemleben, Johannes. 1973. Paracelsus. Revolutionär, Aratund Christ. Frauenfeld-Stuttgart: Huber.

Henry, John. 2008. „The Fragmentation of Renaissance Occultism and the Decline of Magic". History of Science 46: 1-48.

Jütte, Daniel. 2015. The Age of Secrecy: Jews, Christians, and the Economy of Secrets, 1400-1800. New Haven-London: Yale University Press.

Kerckring, Teodor. 1724. Theodori Kerckringii (...) Anmerckungen über Basilii V alentini TriumphWagen des Antimonii. Nürnberg: Adam Jonathan Felßecker.

Koester, Craig R. 2014. Revelation: A New Translation with Introduction and Commentary. New Haven: Yale University Press.

Koetsier, Teun i Karin Reich. 2005. „Michael Stifel and His Numerology”. W Mathematics and the Divine: A Historical Study, red.Teun Koetsier i Luc Bergmans. Amsterdam: Elsevier.

Kooij, Pleun van der, i Carlos Gilly, red. 1998. Fama Fraternitatis. Das Urmanifest der Rosenkereuzer Bruderschaft, zum ersten Mal nach den Manuskripten bearbeitet, die vor dem Erstdruck von 1614 enstanden sind. Haarlem: Rozekruis Pers. [FFU]

Kühlmann, Wilhelm i Joachim Telle, red. 2013. Der Frühparacelsismus. Dritter Teil/ 1, BerlinBoston: De Gruyter.

Latour, Bruno. 2011. Nigdy nie byliśmy nowocześni. Studium z. antropologii symetrycznej. Tłum. Maciej Gdula. Warszawa: Oficyna Naukowa.

Lindbeck, Kristen H. 2010. Elijah and the Rabbis: Story and Theology. New York: Columbia University Press.

Maier, Gerhard. 1981. Die Johannesoffenbarung und die Kirche. Tübingen: Mohr.

Martens, Rhonda. 2000. Kepler's Philosophy and the New Astronomy. Princeton-Oxford: Princeton University Press.

McGinn, Bernard. 1979. Visions of the End: Apocalyptic Traditions in the Middle Ages. New York: Columbia University Press.

McGuire, James E., i Piyo M. Rattansi. 1966. „Newton and the 'Pipes of Pan'.” Notes and Records of the Royal Society of London 21: 108-143.

Melanchton, Philip. 1558. Chronicon Carionis latine expositum et auctum multis et veteribus et recentibus Historiis, in narrationibus rerum Graecarum, Germanicarum \& Ecclesiasticarum a Philippo Melanthone. Wittenberg: Georg Rhau Erben.

Melanchton, Philip. 1844. Chronicon Carionis. W Philippi Melanchtonis Opera quae supersunt omnia, edidit Carolus Gottlieb Bretschneider (Corpus Reformatorum, t. XII). Halle: Schwetschke.

Moran, Bruce T. 1994. „Alchemy, Prophecy and the Rosicrucians: Raphael Eglinus and Mystical Currents of the Early Seventeenth Century". W Alchemy and Chemistry in the 16th and 17th Centuries, red. Piyo Rattansi i Antonio Clericuzio. Dordrecht: Kluwer.

Moran, Bruce T. 2006. Distilling Knowledge: Alchemy, Chemistry, and the Scientific Revolution. Cambridge: Harvard University Press.

Muchowski, Piotr. 1996. Rekopisy znad Morza Martwego. Qumran - Wadi Murabba'at-Masada. Kraków: The Enigma Press.

Naudé, Gabriel. 1623. Instruction à la France sur la verité de l'bistoire des Freres de la Roze-Croix. Paris: F. Julliot. 
Newman, William R. 1994. Gehennical Fire: The Lives of George Starkey, an American Alchemist in the Scientific Revolution. Cambridge: Harvard University Press.

Newman, William R. 1998. „Elias Artista”. W Alchemie. Lexikon einer hermetischen Wissenschaft, red. Claus Priesner i Karin Figala. München: C.H. Beck.

Newman, William R. 2009. „Brian Vickers on Alchemy and the Occult: A Response”. Perspectives on Science 17: 482-506.

Pagel, Walter. 1961. „The Prime Matter of Paracelsus”. Ambix IX(3): 117-135.

Pagel, Walter. 1979. „Paracelsus als “Naturmystiker”. W Epochen der Naturmystik. Hermetische Tradition im wissenschaftlichen Fortschritt, red. Antoine Faivre, RolfCh. Zimmermann. Berlin: Erich Schmidt Verlag.

Pagel, Walter. 1981. „The Paracelsian Elias Artista and the Alchemical Tradition”. Medirinhistorisches Journal 16: 6-19.

Pagel, Walter. 1982. Paracelsus: An Introduction to Philosophical Medicine in the Era of the Renaissance, wyd. 2. Basel-München-Paris-London-New York-Tokyo-Sydney: Karger.

Paracelsus. 1924a. Das Buch Paragranum (Letzte Bearbeitung in vier Abschnitten, 1530). W PSW, t. 8.

Paracelsus. 1924b. Vorrede und erste beide Bücher des Paragranum (1530). W PSW, t. 8.

Paracelsus. 1925. Die drei (vier) Bücher des Opus Paramirum (St. Gallen 1531). W PSW, t. 9.

Paracelsus. 1929. Liber depodagricis et suis speciebus et morbis annexis, liberprimus. W PSW, t. 1.

Paracelsus. 1930a. Von den natürlichen Dingen. Das erst Buch (1525?). W PSW, t. 2.

Paracelsus. 1930b. Das Buch De Mineralibus. W PSW, t. 3.

Paracelsus. 1931. Liber de Imaginibus. W PSW, t. 13.

Paracelsus. 1933a. Libellus de Tinctura Physicorum (1568?). W PSW, t. 14, III: Spuria.

Paracelsus. 1933b. Liber Azoth sive de Ligno et Linea Vitae. W PSW, t. 14, III: Spuria.

Paracelsus. 1965. Von Fasten und Casteien. W Paracelsus, Sämtliche Werke, II. Abt.: Theologische und Religionsphilosophische Schriften, hg. von Kurt Goldammer, t. 2. Wiesbaden: Franz Steiner Verlag.

Petersen, Rodney L. 2013. „The Apocalyptic Luther - Exegesis and Self-Identification”. W The Myth of the Reformation, red. Peter Opitz. Göttingen: Vandenhoeck \& Ruprecht.

Peuckert, Will-Erich. 1973. Das Rosenkereutz, wyd. 2. Berlin: Erich Schmidt Verlag.

Piscator, Johannes. 1613. In Apocalypsin Johannis Commentarius. Herborn: Christoph Corvinus.

Preuss, Hans. 1933. Martin Luther. Der Prophet. Gütersloh: C. Bertelsmann Verlag.

Prinke, Rafał T. 2014. Zwodniczy ogród btẹdów. Piśmiennictwo alchemiczne do końca XV III wieku. Warszawa: Wydawnictwo Instytutu Historii Nauki PAN.

Rattansi, Piyo M. 1972. Newton's Alchemical Studies. W Science, Medicine and Society in the Renaissance. Essays to Honour Walter Pagel, t. II, red. Allen G. Debus. London: Heinemann.

Read, John. 1958. „Gold Making Galore”. New Scientist 4 (101): 1117-1119.

Reich, Karin. 1996. „Zwischen Theologie und Mathematik: Michael Stifels Endchrist (1532)”. W: Rechenmeister und Cossisten der frühen Neuzeit, red. Rainer Gebhardt. AnnabergBuchholz: Adam-Ries-Bund.

Rowland, Christopher. 1979. ,"The Visions of God in Apocalyptic Literature”. Journal for the Study of Judaism 10: 137-154.

Rowland, Christopher. 1982. The Open Heaven: A Study of Apocalyptic in Judaism and Early Christianity. New York: SPCK. 
Sasaki, Chikara. 2003. Descartes's Mathematical Thought. Dordrecht: Springer.

Schelling, Friedrich W.J. von (1927). Vorlesungen über die Methode des akademischen Studiums (1802). W Schellings Werke. Nach der Originalausgabe in neuer Anordnung hg. von Manfred Schröter, 3. Hauptband. München: C.H. Beck - R. Oldenbourg.

Schmidt-Biggemann, Wilhelm. 2004. Philosophia Perennis: Historical Outlines of Western Spirituality in Ancient, Medieval and Early Modern Thought (Archives Internationales d'Histoire des Idées, t. 189). Dordrecht: Springer.

Scholem, Gershom. 1965. Jewish Gnosticism, Merkabah Mysticism, and the Talmudic Tradition, wyd. 2. New York: The Jewish Theological Seminary of America.

Scholem, Gershom. 1987. Origins of the Kabbalah. New York/N.J.: Princeton University Press.

Schweighardt, Theophilus [Daniel Mögling]. 1618. Speculum Sophicum Rhodo-Stauroticum. Das ist: Weitläuffige Entdeckung deß Collegij unnd axiomatum von der sondern erleuchten Fraternitet ChristRosenCreutr. B.m. [Frankfurt nad Menem?]: b.w.

Shapin, Steven. 2000. Rewolucja naukowa. Tłum. Stefan Amsterdamski. Warszawa: Prószyński i S-ka.

Shea, William R. 1988. Descartes and the Rosicrucian Enlightenment. W Metaphysics and Philosophy of Science in the Seventeenth and Eighteenth Centuries: Essays in Honour of Gerd Buchdahl, red. R.S. Woolhouse. Dordrecht-Boston-London: Kluwer.

[Siebmacher, Johann Ambrosius]. 1618. Introductio Hominis, oderkurtze Anleitung zu einem Christlichen Gottseligen Leben. W Philosophia Mystica, darinn begriffen Eilff unterschidene Theologico-Philosophische, doch teutsche Tractätlein... Newstadt: Lucas Jennis.

Sperber, Julius. 1660. Ein Geheimer Tractatus Iulii Sperberi Von den dreyen seculis oder Hauptzeiten von Anfang bis zum Ende der Welt. Amsterdam: Benedictus Bahnsen.

Stone, Michael E. 1976. „Lists of Revealed Things in the Apocalyptic Literature”. W Magnalia Dei: The Mighty Acts of God. Essays on the Bible and Archaeology in Memory of G. Ernest Wright, red. Frank M. Cross, Werner E. Lemke i Patrick D. Miller. Garden City/N.Y.: Doubleday.

Stone, Michael E. 1980. Scriptures, Sects and Visions: A Profile of Judaism from Ezra to the Jewish Revolts. Philadelphia: Fortress.

Stuckrad, Kocku von. 2010. Locations of Knowledge in Medieval and Early Modern Europe: Esoteric Discourse and Western Identities. Leiden-Boston: Brill.

Suchodolski, Bogdan. 1963. Narodziny nowożytnej filozofii człowieka. Warszawa: PWN.

Thorndike, Lynn. 1956. „The Latin Translation of Astrological Works by Messahala”. Osiris 12: 49-72.

Trepp, Anne-Charlott. 1999. „Religion, Magie und Naturphilosophie. Alchemie im 16. und 17. Jahrhundert”. W Im Zeichen der Krise. Religiosität im Europa des 17. Jabrhunderts, red. Hartmut Lehmann i Anne-Charlott Trepp. Göttingen: Vandenhoeck \& Ruprecht.

Trepp, Anne-Charlott. 2009. Von der Glückseligkeit alles zu wissen. Die Erforschung der Natur als religiöse Praxis in der Frühen Neuzeit. Frankfurt am Main: Campus Verlag.

Trevor-Roper, Hugh. 1985. „The Paracelsian Movement”. W Renaissance Essays, red. Hugh Trevor-Roper. Chicago: University of Chicago Press.

Vickers, Brian. 1984. „Analogy versus Identity: The Rejection of Occult Symbolism, 1580_ 1680”. W Occult and Scientific Mentalities in the Renaissance, red. Brian Vickers. CambridgeLondon-New York: Cambridge University Press. 
Wallmann, Johannes. 1982. „Zwischen Reformation und Pietismus. Reich Gottes und Chiliasmus in der lutherischen Orthodoxie". W Verifikationen. Festschriftfür Gerhard Ebeling ₹um 70. Geburtstag, red. Eberhard Jüngel. Tübingen: J.C.B. Mohr.

Walton, Michael T. 2015. „The Chemical Philosophy and Kabbalah: Pantheus, Khunrath, Croll, and the Treasures of the Oratory and the Laboratory". W Bridging Traditions: Alchemy, Chemistry and Paracelsian Practices in the Early Modern Era, red. Karen H. Parshall, Michael T. Walton i Bruce T. Moran. Kirksville/MO: Truman State University Press.

Webster, Charles. 1992. Od Paracelsusa do Newtona. Magia i powstanie nowoṡytnej nauki. Tłum. Klara Kopcińska i Artur Zapałowski. Warszawa: IFiS PAN.

Webster, Charles. 2002. The Great Instauration: Science, Medicine and Reform, 1626-1660, wyd. 2. Frankfurt am Main: Peter Lang.

Weeks, Andrew. 1997. Paracelsus: Speculative Theory and the Crisis of the Early Reformation. Albany: State University of New York Press.

Wollgast, Siegfried. 1993a. ,Zur Wirkungsgeschichte des Paracelsus im 16. und 17. Jahrhundert". W Resultate und Desidarate der Paracelsus-Forschung, red. Peter Dilg i Hartmut Rudolph. Stuttgart: Franz Steiner Verlag.

Wollgast, Siegfried. 1993b. Philosophie in Deutschland zwischen Reformation und Aufklärung 1550_ 1650, wyd. 2. Berlin: Akademie-Verlag.

Woszczek, Marek. 2009. „Newton-alchemik i imaginacyjne drogi fizyki”. W W kregu filozofii nauki, kultury i społeczeństwa, red. Tadeusz Buksiński i Elżbieta Pakszys. Poznań: Wyd. Naukowe IF UAM.

Yates, Frances. 1964. Giordano Bruno and the Hermetic Tradition. Chicago-London: University of Chicago Press. 
Marek Woszczek - filozof, adiunkt w Zakładzie Filozofii Nauki Instytutu Filozofii UAM w Poznaniu. Zajmuje się ontologia przyrody i filozofia fizyki. Prowadzi także badania nad wybranymi problemami historii i filozofii religii, w szczególności historiąinterakcji dyskursów religijno-teologicznych i naukowo-przyrodoznawczych, od wczesnonowożytnej nauki po romantyczną Naturphilosophie. Autor książki Platonic Wholes and Quantum Ontology, Frankfurt am Main 2015 (1. wyd. pol.: Ukryta catość prayrody a mikrofizylka, Poznań 2010). Laureat nagrody naukowej Prezesa Rady Ministrów (2010).

\section{DANE ADRESOWE:}

Instytut Filozofii UAM

ul. Szamarzewskiego 89c

60-568 Poznań

EMAIL: marwos@amu.edu.pl

CYTOWANIE: Woszczek, Marek. 2016. Eliasz nauk. Apokaliptyka, paracelsjańska mistyka przyrody i narodziny nowoczesności (część pierwsza). Praktyka Teoretycżna 1(19): 126-171.

DOI: $10.14746 /$ prt.2016.1.8

AUTHOR: Marek Woszczek

TITLE: Elijah of the Arts: Apocalypticism, Paracelsian Mysticism of Nature, and the Origins of Modernity

ABSTRACT: The myth of $[\mathrm{H}]$ Elias Artista (or 'Elijah of the Arts') is one of the most interesting components of the rich 16th-century Paracelsian tradition from the margins of the post-Reformation orthodoxy. It signals a surprising development within the Christian apocalyptic tradition since 'Helias artium chymicarum', the messianic Experimentator as a human Christ-like figure and an end-of-time counterpart of the biblical blacksmith Tubal-cain, is an original transformation of the Jewish apocalyptic Elijah in a context of the early modernity on the eve of the Thirty Years War. That figure is an example from the broader domain of the Paracelsian 'theoalchemy' (Telle), which may be construed as a typically modern hybrid in the Latourian sense. Furthermore, in order to understand the peculiar post-Reformation phenomenon of the mysticism of nature (Dorn, Khunrath, Gutman, Arndt, Boehme, and others), which is in stark tension with orthodox theologies, it is necessary to take into account that it was a product of the new powerful intellectual formation which can be dubbed the nature (orcosmological) apocalypticis m. 
It is claimed that that 'vertical' (non-eschatological) apocalypticism of nature is an early modern form of the ancient Jewish apocalyptic tradition transformed under the new socialcultural conditions into a formula of the 'learning the secrets of nature' in a complex process of renegotiating the power relations, and it produced the ample resource of the cognitive motivations for experimental activity, quite independently of the gradually waning millenarian affects. Thus, that transformation is important for understanding the religious early modernity and its immanentist, activist attitudes and getting beyond the one-dimensional discourses of the secularization paradigm, which obliterates or ignores the 'vertical' axis of apocalypticism and fixes itself upon the horizontal (millenarian) dimension while (re)constructing the criticized unpicturesque 'irreligion of progress' (Löwith). Early modernity could be better understood as a diffused turn (effect) associated with the innovative material (e.g. medical or chemical) practices and their new conceptualisations of matter and knowledge, where philosophy, theology, science of matter and social revolt seem inseparable. The myth of the Elijah of the Arts, contrary to a superficial secularization interpretation, is one of the symptoms of the growing process of 'de-eschatologization' through the alternative direction of apocalypticism, i.e., shifting an interest to nature and matter as the religious objects available to exploration, which produced the new power conflicts typical of modernity but also the 'laboratory' as a space of unveiling that which is hidden in nature.

KEYWORDS: early modernity, nature (cosmological) apocalypticism, myth of Elias Artista, mysticism of nature, Paracelsian alchemy, matter, pantheism, ontology of expression 